\title{
Moderating Effects of Agency Problems and Monitoring Systems on the Relationship between Executive Stock Option and Audit Fees: Evidence from Korea
}

\author{
Sang Cheol Lee ${ }^{1, *}$, Jaewan Park ${ }^{1}$, Mooweon Rhee ${ }^{2}$ and Yunkeun Lee ${ }^{1}$ \\ 1 College of Business Administration, Dongguk University-Seoul, 30, Pildong-ro 1gil, Jung-gu, Seoul 04620, \\ Korea; jwpark@dongguk.edu (J.P.); yunkeun69@gmail.com (Y.L.) \\ 2 School of Business, Yonsei University, 50 Yonsei-ro, Seodaemun-gu, Seoul 03722, Korea; \\ mooweon@yonsei.ac.kr \\ * Correspondence: sclee68@dongguk.edu; Tel.: +82-2-2260-3899
}

Received: 17 October 2018; Accepted: 31 October 2018; Published: 4 November 2018

check for updates

\begin{abstract}
Since executive stock options may give rent-seeking incentives to CEOs, CEOs with stock options are likely to misallocate corporate resources to seek personal gains, which in turn may lead to a decrease in firm value. High-quality audit services can reduce the negative impacts of executive stock options on firm value and help firms to ensure sustainable growth. However, while most of the existing accounting literature related to executive stock options (ESO) is mainly focused on earnings management, there are relatively few studies that investigate the relation between ESO and audit fees. At the same time, while previous studies on ESO have been conducted in advanced countries, few studies have identified the relationship between ESO and audit fees in emerging markets. Therefore, it is necessary to examine the effect of ESO under circumstances different from those of developed countries. To fill this gap, we investigated the association between executive stock options and audit fees and examine the moderating effects of agency problems and monitoring systems on the relationship. Using 462 observations from 110 nonfinancial Korean listed companies, for the period of 2000 to 2005, we found that executive stock options are positively related to audit fees. In addition, we found that the effects of executive stock options on audit fees are even higher in firms with high agency problems, effective internal monitoring systems, and major accounting firms. This study can help regulatory agencies to validate audit fee regulations, such as the International Standard on Auditing, that consider ESO a significant risk factor. In addition, these results can help external auditors to set up the specific guidelines for pricing audit fees. Furthermore, the results of this study will contribute to the construction of more desirable corporate governance structure in Korean companies, which in turn would not only enhance firm value but also strengthen the sustainability of companies belonging to the emerging markets.
\end{abstract}

Keywords: executive stock options; audit fees; agency problems; monitoring systems

\section{Introduction}

Executive stock options (hereafter simply referred to as ESO) can align the interests of managers with the interests of shareholders [1] and induce managers to take more risks [2]. However, recent studies suggest that ESO provide managers with incentives to manipulate the firm's reported earnings [3,4]. Therefore, managers with ESO might override the internal control system to manage the reported earnings, leading to an increase in control risk, a type of audit risk. 
If external auditors need to detect such opportunistic behaviors by management with ESO to eliminate audit failure and to protect their reputation capital in a situation with earnings management, they might perform the audit in more time and demand higher audit fees for the firms granted ESO [5]. Since ESO can influence the degree of audit risk, external auditors will take this effect into consideration in negotiating audit fees. According to the International Standard on Auditing (ISA) No. 240, The Auditor's Responsibilities Relating to Fraud in an Audit of Financial Statements, external auditors actually take ESO into consideration as a significant risk factor relating to misstatements arising from fraudulent financial reporting. (In addition, the International Standard on Auditing (ISA) No. 315, Understanding the Entity and Its Environment and Assessing the Risk of Material Misstatements, presents guidance on matters which external auditors may consider to assess risk. Therefore, ISA No. 240 and No. 315 consider ESO a significant risk factor.).

While most of the existing accounting literature related to ESO is mainly focused on earnings management, there are relatively few studies that investigate the relation between ESO and audit fees. At the same time, while previous studies on ESO have been conducted in advanced countries, few studies have identified the relationship between ESO and audit fees in emerging markets. Therefore, it is necessary to examine the effect of ESO under circumstances different from those of developed countries.

We chose Korea as our research setting for the following reasons. The stock option system was introduced in Korea in 1997 and most of the stock options were granted only at the beginning of 2000. At the same time, as audit fees have been unregulated since 1999, auditors can determine audit fees under open negotiation between auditors and clients, which makes it possible for auditors to determine audit fees by reflecting a client's audit risk. Therefore, we can clearly identify the effect of ESO on audit fees. Furthermore, since Korea has made rapid and significant progress in its corporate governance system since its financial crisis in the late 1990s, we can clearly identify the effect of internal monitoring systems on the relationship between ESO and audit fees. As a result, this study investigates the effect of the executive stock option on audit fees under the Korean corporate governance structure, which is different from those of developed countries, so the study has significant opportunities to apply to the improvement of corporate governance structure in countries belonging to the category of emerging markets.

In this study, we explored two research questions: What are the effects of ESO on audit fees? What are the moderating effects on the association between ESO and audit fees? Using 462 observations from 110 nonfinancial Korean companies, for the period of 2000 to 2005, we found that ESO are positively related to audit fees. We also found that the effects of ESO on audit fees are even higher in firms with high agency problems, effective internal monitoring systems, and major accounting firms. Using these test results, we can verify the validity of the regulation and help external auditors to set up the guidelines on fees for audits. Moreover, this study investigated the effect of ESO under Korean corporate governance systems different from those of developed countries, so the study has significant opportunities to be applied in the improvement of corporate governance structure in countries belonging to the category of emerging markets.

The next section reviews previous studies and develops our hypothesis. Section 3 presents the empirical design and measures. Section 4 details the test results. Section 5 concludes and offers direction for future research.

\section{Literature Review and Hypothesis Development}

\subsection{Relationship between Executive Stock Options and Audit Fees}

Prior research provided evidence on the various incentives for firms' managers to manage reported earnings. Managers have an incentive to manipulate reported earnings in order to influence short-term stock price [6-8]. Managers also have an incentive to manage reported earnings to increase their profits from stock-related compensation $[9,10]$. At the same time, managers are likely to manage 
earnings around initial public offerings or at the time of seasoned equity offering issuance $[8,11,12]$. Likewise, managers of $R \& D$ firms have a greater propensity to achieve earnings smoothness than other managers do [13]. Furthermore, recent studies presented that earnings management strategies are not just limited to overstatement of accruals, but expanded to manipulate real activities [14].

With a higher risk of earnings management, auditors are likely to increase audit efforts, thus resulting in increasing audit fees [15]. If auditors consider executive stock option a risk factor which is related to decision making for audit fees, executive stock option can be a major determinant of audit fees. Therefore, based on the empirical evidence that executive equity incentives affect earnings management, auditing standards such as ISA suggest that auditors regard executive equity compensation as a risk factor when evaluating client firm's risk of misstatements.

However, there is relatively little research on whether executive equity incentives such as stock option affect auditors' risk assessments and pricing decisions. Using U.S. firm-year observations from 1992 to 2006, Kuang and Qin (2013) [16] analyzed the association between managerial compensation incentives for risk taking and credit ratings, and provided the evidence that rating agencies impound managerial risk-taking incentives (both vega and delta) in their risk assessments. Using the U.S. Audit Analytics database for the period 2000-2010, Fargher et al. (2014) [17] found evidence that executive equity incentives as proxies for managerial risk-taking incentives have a significant impact on audit fees, as well as the issuance of going-concern audit opinions. With the U.S. Audit Analytics database for the period 2000-2009, Kim and Li (2015) [18] presented evidence that CEO equity portfolio vega has a positive impact on audit fees and a significant audit fee increase when firms issue CEO stock options for the first time in three years. They also suggested that auditors perceive greater audit risk associated with CEO equity incentives and incorporate such risk in audit pricing decisions.

In these respects, external auditors are expected to regard such potentially opportunistic behaviors by management holding ESO as a control risk in the list of audit risks. Because external auditors want to minimize the risk of material misstatement in financial statements, they might take more time to perform the audit and demand higher audit fees for the firms granted ESO. Therefore, if the existence of an ESO influences the degree of audit risk, external auditors will take this effect into consideration in negotiating audit fees. As a result, if ESO is considered to increase audit risk, external auditors will demand higher audit fees for firms granted ESO.

Hypothesis 1a. Audit fees for firms granted stock options to executives are higher than audit fees for firms without ESO.

Executives' incentive to manage reported earnings can also vary with the portions of ESO compensation in total management compensation [3,4,19]. Bergstresser and Philippon (2006) [3] documented that discretionary accruals as a measure of earnings management appear high in cases where the ratio of ESO compensation to total executive compensation is high. Burns and Kedia (2006) [19] also found that earnings restatement is positively related to the portions of performance-contingent compensation, such as ESO. Peng and Roell (2008) [4] showed that a larger number of vested ESO has a significant impact on earnings manipulation, which in turn increases the probability of litigation. Therefore, the higher the ratio of ESO compensation to total compensation is, the higher the audit risk is. As a result, external auditors will demand higher audit fees for firms with an ESO.

Hypothesis $\mathbf{1 b}$. The higher the ratio of ESO compensation to total compensation is, the higher audit fees will be.

\subsection{Moderating Factors Affecting the Relationship between ESO and Audit Fees}

\subsubsection{Agency Problems}

Traditional agency problems might arise when managers' interests do not fully overlap with those of shareholders [20]. Managers' opportunistic behavior can be particularly severe in high 
agency problems between shareholders and managers when managerial actions are difficult to observe. Therefore, the more frequent the agency conflicts between shareholders and managers are, the larger the managers' incentives become not to report their firms' financial results transparently [21], which can increase audit fees [22]. The reason is that external auditors take longer to perform the audit to prevent misstatement of financial statements associated with moral hazard and adverse selection problems [23] and demand higher audit fees to compensate for the increased audit risk. As a result, it is expected that when ESO is awarded to non-owner managers with more severe agency problems, audit fees will be even higher.

Hypothesis 2a. The effect of ESO on audit fees is higher for non-owner managers than those for owner managers.

In Korea, majority stockholders of a Chaebol (Chaebol refers to a Korean form of business conglomerate.) can exercise more control rights using the complicated pyramidal and cross-holding ownership than their pro rata cash flow rights, which might generate another agency problem between majority owners and minority owners. Accordingly, majority shareholders of a big conglomerate have an incentive to transfer the wealth of minority shareholders into their own [24]. In addition, managers of conglomerate firms might not be free to make decisions against majority shareholders and might be more involved in manipulating reported earnings $[25,26]$. Therefore, when there are greater agency problems between majority owners and minority owners, external auditors demand higher audit fees in order to compensate for the increased audit risk. Fan and Wong (2005) [27] found a positive relation between ownership concentration and audit fees, explaining that auditors ask for an additional premium to their clients that are Asian firms with higher agency conflicts between controlling and minority shareholders. As a result, when ESO are awarded to managers of conglomerate firms with more severe agency problems between majority owners and minority owners, audit fees will be even higher.

Hypothesis $\mathbf{2 b}$. The effect of ESO on audit fees is larger for firms belonging to a conglomerate.

\subsubsection{Internal Monitoring Systems}

When the board of directors is more independent, it can increase the incentive to monitor the financial reporting process effectively $[28,29]$. Because an independent board of directors demands high-quality auditors to avoid the negative consequences (e.g., damage to reputation or litigation) of poor financial reporting quality, the board of directors is more likely to select a high-quality auditor, which results in higher audit fees [30]. What is more, Hay et al. (2008) [31] documented that there is a complementary relationship between an internal board's monitoring and an external audit. Therefore, the independent board may choose a high-quality external auditor and pay higher audit fees. As a result, we expect that firms with more independent board members show a greater effect of ESO on audit fees.

Hypothesis 3a. The effect of ESO on audit fees is higher for firms with more independent board members.

The independent directors' activities on the board of directors play a critical role in monitoring management. When the boards monitor managers actively and directors operate boards effectively, the risk of accounting fraud can be reduced [28]. As the percentage of outside directors attending board meetings increases, outside directors participate in active monitoring and demand a higher quality of audit services to complement their monitoring responsibilities [32]. Therefore, we expect more active boards to demand a higher quality of audit services, resulting in higher audit fees.

Hypothesis $3 \mathbf{b}$. The effect of ESO on audit fees is higher when the attendance rate for outside directors at board meetings is high. 
Boards often delegate their oversight function to audit committees to take advantage of audit committees' accounting or related financial management expertise. Since audit committees exercise strict control over the auditing process and quality of financial reporting, audit committees can reduce the risk of accounting fraud [33-35]. Hay et al. (2008) [31] suggest that the audit committee serves as the complement to an external auditor in monitoring management. In these respects, we want to test the following hypothesis.

Hypothesis 3c. The effect of ESO on audit fees is higher for firms with audit committees.

\subsubsection{External Auditors}

Larger audit firms tend to provide higher quality audits [36]. Because big audit firms with a good reputation have a higher level of personnel training and expertise, they can earn an audit fee premium in return for providing a higher quality of audited financial statements [37,38]. In addition, large audit firms are likely to have greater insurance coverage in the event of audit failure. In this respect, the fee premium of large audit firms could be interpreted as the price paid by clients, signaling their quality, for an auditor of superior reputation and expertise [39,40]. Therefore, we expect that the effect of ESO on audit fees is higher when large auditing firms are engaged.

Hypothesis 4. The effect of ESO on audit fees is higher for firms employing big auditing firms.

\section{Research Method}

\subsection{Sample Selection}

The samples for this study consist of companies listed on the Korea Exchange as nonfinancial companies from the year 2000 to 2005, during which most firms granted stock options to their managers. The stock option was introduced in Korea in 1997 and most stock options were only offered regularly from the beginning of 2000. However, the trend of offering stock options to management in Korea peaked in 2004 and the number of companies that newly introduced stock options has decreased since 2005. Therefore, as Korean companies have rarely given stock options to their managers from 2006 onwards, it is difficult to obtain executive stock option data for analysis after 2006. At the same time, as audit fees had been regulated until 1999 in Korea, it is possible for auditors to determine audit fees by reflecting a client's audit risk. Therefore, we excluded the years 1998 and 1999 from our sample. Considering the above aspects, it is reasonable that the sampling period must cover the period from 2000 to 2005.

The samples were singled out for analysis based on the fair value of stock options, which can be calculated using the Black-Scholes Option Pricing Model, in accordance with the SKAS (Statements of Korean Accounting Standards) No. 22 (Stock-based Payment). Firms in the banking and finance industry were excluded from this study in order to enhance the comparability of the data collected from the samples. Firms which do not disclose relevant information in calculating stock option compensation expense amounts in the footnote to the financial statements were excluded from our samples. We also removed the unusual observations that have values exceeding plus or minus three standard deviations from the average. Based on above criteria, 231 firm-year observations were selected as samples with ESO.

Control samples were selected for comparison with firms with ESO. Using four matching criteria such as fiscal year-end date, industry, firm size, and size of audit firms, we selected 231 control samples. Therefore, our final total samples consisted of 462 firm-year data. The sampling process and sample distribution by year and industry are explained in Table 1 . Panel A of Table 1 summarizes the sample selection process and sample distribution by year, and Panel B of Table 1 describes sample distribution by industry. Our sample distribution by industry is similar to previous literature [41,42]. We collected executive compensation data using the electronic disclosure system of the Korean Financial Supervisory 
Service, and other data by searching KisValue, which is a financial database of Korea Information Service, Inc. in Seoul, Korea.

Table 1. Sample Selection Process and Distribution.

Panel A: Sample Selection Process and Distribution by Year

\begin{tabular}{lccccccc}
\hline & $\mathbf{2 0 0 0}$ & $\mathbf{2 0 0 1}$ & $\mathbf{2 0 0 2}$ & $\mathbf{2 0 0 3}$ & $\mathbf{2 0 0 4}$ & $\mathbf{2 0 0 5}$ & Total \\
\hline Observations with ESO & 28 & 32 & 44 & 48 & 49 & 55 & 256 \\
Excluded: Data availability & & & 4 & 6 & 8 & 4 & 22 \\
Excluded: Unusual observation & & & 1 & 1 & & 1 & 3 \\
Analysis Sample & 28 & 32 & 39 & 41 & 41 & 50 & 231 \\
Control Sample & 28 & 32 & 39 & 41 & 41 & 50 & 231 \\
Final sample & 56 & 64 & 78 & 82 & 82 & 100 & 462 \\
\hline
\end{tabular}

Panel B: Sample Distribution by Industry

\begin{tabular}{lcccc}
\hline \multicolumn{1}{c}{ Industry } & $\begin{array}{c}\text { With } \\
\text { ESO }\end{array}$ & Without ESO & Total & Percentage (\%) \\
\hline Food and Beverage & 5 & 5 & 10 & 2.16 \\
Clothing and Textile & 2 & 2 & 4 & 0.87 \\
Pulp and Paper & 14 & 14 & 28 & 6.06 \\
Oil and Tobacco & 25 & 25 & 50 & 10.82 \\
Chemicals & 40 & 40 & 80 & 17.32 \\
Metal & 13 & 13 & 26 & 5.63 \\
Other Machinery and equipment & 16 & 16 & 32 & 6.93 \\
Medical equipment and other & 22 & 22 & 44 & 9.52 \\
Electrical machinery and other & 6 & 6 & 12 & 2.60 \\
Electronics and Communication equipment & 45 & 45 & 90 & 19.48 \\
Automobile and Trailer & 12 & 12 & 24 & 5.19 \\
Other Transportation equipment & 6 & 6 & 12 & 2.60 \\
Furniture and other & 1 & 1 & 2 & 0.43 \\
Wholesale and Retail & 1 & 1 & 2 & 0.43 \\
Professional, Scientific and Technical services & 23 & 23 & 46 & 9.96 \\
& 231 & 231 & 462 & 100 \\
\hline
\end{tabular}

Notes: Table 1 presents the sampling process and sample distribution by year and industry. Panel A of Table 1 summarizes the sample selection process and sample distribution by year, and Panel B of Table 1 describes the sample distribution by industry.

\subsection{Variable Measurements}

\subsubsection{Executive Stock Options and Audit Fees}

Two types of ESO, the existence of ESO and the portion of ESO to total executive compensation, were identified for this study. The existence of ESO (ESO) is a dichotomous variable set at one if the firm grants ESO to its executives. The portion of ESO to total executive compensation (PESO) was measured as the ratio of stock option-based compensation to total executive compensation. Using the Black-Scholes Option Pricing Model, we computed the fair value of stock options, which is calculated by multiplying the unit compensation expense of the stock options via the fair-value approach by the quantity of unexercised ESO. In addition, we calculated total executive compensation as a sum of the stock option-based compensation amount and the other cash compensation amount.

We regarded audit fees as a surrogate for external auditors' effort. To improve the linearity between audit fees and explanatory variables, we measured the audit fees by the natural log of audit fees (LN(AF)) [31,43-45].

\subsubsection{Agency Problems and Monitoring Mechanisms}

Under the traditional agency theory, managerial ownership is a substitute mechanism for reducing agency problems between managers and outside shareholders in all-equity firms [20]. Therefore, 
we measured the level of agency problems between managers and shareholders by the percentage of management ownership (MO).

Meanwhile, Fan and Wong (2005) [27] found that auditors ask for an additional premium to their clients that are Asian firms with higher agency problems between controlling and minority shareholders. In Korea, large conglomerate firms are often referred to as Chaebols. Each year, the Korea Fair Trade Commission (KFTC) ranks Chaebols in the country based on the size of their assets, identifying the 30 largest conglomerates that are prohibited from cross-equity holding and cross-debt guarantees [46]. Therefore, an indicator variable (CB) is used for classifying conglomerate-affiliated companies. If a company under consideration belongs to Korea's top 30 conglomerates, the value of 1 is given to the variable, and otherwise, 0 .

In this study, we included the independence of the boards, activity of the boards, and existence of audit committees as variables to measure internal monitoring mechanisms. Since more independent boards might support the purchase of a greater amount of external auditing services, thus leading to increased audit fees [44], we measured the percentage of outside directors on the board as the board independence (BI) $[28,29]$. Because outside directors are expected to actively participate in the board meetings in order to discharge their responsibility effectively, thus resulting in audit fee increases [44], we used the proportion of outside directors' attendance and participation at board meetings as the activity of outside directors on the board (BACT). Because the audit committee can demand high-quality audit service with wider scope and greater assurance from the existing external auditor $[30,44,47]$, the existence of audit committees might have a positive relationship with audit fees [30,47]. Thus, we calculated the existence of audit committees (AC) as a dichotomous variable set at one if firms have their own audit committees.

Because big audit firms may bear much higher risks, such as litigation and loss of reputation in case of audit failure, they have much more incentive to provide a high quality of audit services [48]. Therefore, audit firm size can be used as a surrogate for audit quality $[40,43,49]$. In this paper, we used the audit firm size (BIG) as a dummy variable set at one if the external auditor belongs to the Big 4-affiliated audit firms.

\subsubsection{Control Variables}

Total assets are measured as the log of total assets to control for firm size serving as a proxy for audit effort [22,43,50,51]. To control for audit complexity, we chose receivables, inventory, overseas sales, and the number of segments. All these variables were expected to be positively related to audit fees. Receivables are measured as the ratio of receivables to total assets and inventory is denoted as the ratio of inventory to total assets $[43,44,52]$. Overseas sales are the ratio of foreign segment sales to total assets [43,53]. Number of segments is computed as the number of business segments [53,54].

To control for audit risk, we also included debt to assets ratio, return on assets, and negative earnings [54-57]. Among these variables, debt to assets ratio and negative earnings were expected to be positively related to audit fees; however, return on assets was expected to be negatively related to audit fees. Debt to assets ratio is the ratio of total liabilities to total assets. Return on assets is expressed as earnings before interest and taxes divided by total assets. Negative earnings is an indicator variable for firm-years with negative earnings.

To control for the influence of external auditor characteristics on audit fees, we employed auditor size, auditor tenure, and the existence of non-audit fees. We measured auditor size using a dummy variable coded 1 if the auditor is a member of the first tier of auditor (the Big 4: PriceWaterhouseCoopers, Deloitte Touche Tohmatsu, Earnst and Young, and KPMG), otherwise coded 0. $[40,43]$. Because of knowledge spillover effects, the longer the auditor tenure is, the lower the audit time and audit fees are. On the other hand, because of the presence of a 'low balling' audit strategy, the longer the auditor tenure is, the higher the audit fees are. Considering the effect of auditor tenure on audit fees, we included in our model's auditor tenure a dummy variable to signify whether the duration of auditor tenure is 3 years or more ( 1 if yes, 0 if no). It was found that the provision of 
non-audit services is significantly related with audit fees, but the empirical results of previous studies on effects of audit fees on non-audit fees were mixed [58-62]. To control the effect of non-audit fees on audit fees, we introduced a dummy variable into the models: The provision of non-audit services ( 1 if yes, 0 if no). Finally, we controlled for industry and year effects.

\subsection{Research Model}

We set the following regression Model (1) to examine the relationship between executive stock options and audit fees.

\section{Model (1)}

$$
\begin{aligned}
& \mathrm{LN}(\mathrm{AF})_{\mathrm{i}, \mathrm{t}}=\alpha+\beta_{1} \mathrm{ESO}_{\mathrm{i}, \mathrm{t}}\left[\mathrm{PESO}_{\mathrm{i}, \mathrm{t}}\right]+\beta_{2} \mathrm{LN}(\mathrm{TA})_{\mathrm{i}, \mathrm{t}}+\beta_{3} \mathrm{REC}_{\mathrm{i}, \mathrm{t}}+\beta_{4} \mathrm{INV}_{\mathrm{i}, \mathrm{t}}+\beta_{5} \mathrm{OS}_{\mathrm{i}, \mathrm{t}} \\
& +\beta_{6} \mathrm{SEG}_{\mathrm{i}, \mathrm{t}}+\beta_{7} \mathrm{LEV}_{\mathrm{i}, \mathrm{t}}+\beta_{8} \mathrm{ROA}_{\mathrm{i}, \mathrm{t}}+\beta_{9} \mathrm{LOSS}_{\mathrm{i}, \mathrm{t}}+\beta_{10} \mathrm{BIG}_{\mathrm{i}, \mathrm{t}}+\beta_{11} \mathrm{IA}_{\mathrm{i}, \mathrm{t}}+\beta_{12} \mathrm{NAF}_{\mathrm{i}, \mathrm{t}} \\
& +\beta_{\mathrm{i}} \mathrm{IND}_{\mathrm{i}}+\beta_{\mathrm{t}} \mathrm{YEAR}_{, \mathrm{t}}+\varepsilon_{\mathrm{i}, \mathrm{t}}
\end{aligned}
$$

where:

LN(AF): The log of audit fees,

ESO: An indicator variable equal to 1 if the firm has ESO, otherwise 0 ,

PESO: The ratio of the value of ESO to total executive compensation,

LN(TA): The log of total assets,

REC: The ratio of receivables to total assets,

INV: The ratio of inventories to total assets,

OS: The ratio of sales outside Korea to total assets,

SEG: The number of segments,

LEV: The ratio of total liabilities to total assets at the end of the year,

ROA: Earnings before interest and taxes divided by total assets,

LOSS: An indicator variable equal to 1 if the firm reports a net loss in the 3 consecutive years, 0 otherwise,

BIG: An indicator variable equal to 1 if the firm is audited by a Big 4 accounting firm during the current year, 0 otherwise,

IA: An indicator variable equal to 1 if the firm employs a new auditor, otherwise 0 ,

NAF: An indicator variable equal to 1 if the firm has the non-audit services, otherwise 0 ,

IND: An indicator variable to manifest the industry to which the firm belongs,

YEAR: An indicator variable to signify the year to which each observation belongs.

Model (1) determines the effect of the existence of ESO or the portion of ESO to total executive compensation on audit fees. When considering the existence of ESO (ESO), an independent variable in Model (1), we used the total samples consisting of 462 firm-year data, which included both 231 observations with ESO and their matched samples of 231 observations. In Model (1), regarding the portion of ESO to total executive compensation (PESO) as an independent variable, we used only 231 observations with ESO. Taking Hypothesis $1 \mathrm{a}, \mathrm{b}$, we expected that $\beta_{1}$, the coefficient of the ESO or PESO, in Model (1) is positive and statistically significant. Among control variables, total assets (LN(TA)), receivables (REC), inventories (INV), overseas sales (OS), the number of segments (SEG), leverage (LEV), loss history (LOSS), and non-audit fees (NAF) were expected to be positively related to audit fees. On the contrary, return on investment (ROA) and initial audit (IA) were expected to be negatively related to audit fees.

To investigate whether the prediction of audit fees from executive stock options differs across levels of agency problem and monitoring mechanisms, we used the following moderation Model (2), with agency problem and monitoring mechanisms as additional independent variables and their interaction terms $(\mathrm{PESO} \times \mathrm{AP}(\mathrm{IMM}$, or EA)) between the portion of ESO to total executive compensation and moderating variables. 
Model (2)

$$
\begin{aligned}
& \mathrm{LN}(\mathrm{AF})_{\mathrm{i}, \mathrm{t}}=\alpha+\beta_{1} \mathrm{PESO}_{\mathrm{i}, \mathrm{t}}+\beta_{2} \mathrm{AP}_{\mathrm{i}, \mathrm{t}}\left[\mathrm{IMM}_{\mathrm{i}, \mathrm{t}} \text { or } \mathrm{EA}_{\mathrm{i}, \mathrm{t}}\right]+\beta_{3} \mathrm{PESO}_{\mathrm{i}, \mathrm{t}} \times \mathrm{AP}_{\mathrm{i}, \mathrm{t}}\left[\mathrm{PESO}_{\mathrm{i}, \mathrm{t}} \times\right. \\
& \left.\mathrm{IMM}_{\mathrm{i}, \mathrm{t}} \text { or } \mathrm{PESO}_{\mathrm{i}, \mathrm{t}} \times \mathrm{EA}_{\mathrm{i}, \mathrm{t}}\right]+\beta_{4} \mathrm{LN}(\mathrm{TA})_{\mathrm{i}, \mathrm{t}}+\beta_{5} \mathrm{REC}_{\mathrm{i}, \mathrm{t}}+\beta_{6} \mathrm{INV}_{\mathrm{i}, \mathrm{t}}+\beta_{7} \mathrm{OS}_{\mathrm{i}, \mathrm{t}}+\beta_{8} \mathrm{SEG}_{\mathrm{i}, \mathrm{t}}+ \\
& \beta_{9} \mathrm{LEV}_{\mathrm{i}, \mathrm{t}}+\beta_{10} \mathrm{ROA}_{i, \mathrm{t}}+\beta_{11} \mathrm{LOSS}_{\mathrm{i}, \mathrm{t}}+\beta_{12} \mathrm{BIG}_{\mathrm{i}, \mathrm{t}}+\beta_{13} \mathrm{IA}_{\mathrm{i}, \mathrm{t}}+\beta_{14} \mathrm{NAF}_{\mathrm{i}, \mathrm{t}}+\beta_{\mathrm{i}} \mathrm{IND}_{\mathrm{i}}+\beta_{\mathrm{t}} \mathrm{YEAR}_{\mathrm{t}}+\varepsilon
\end{aligned}
$$

where:

AP (Agency Problems) variables:

MO: The percentage of management ownership,

$\mathrm{CB}$ : An indicator variable equal to 1 if the management belongs to the affiliated companies of the

Korean conglomerate group called 'Chaebol', otherwise 0.

IMM (Internal Monitoring Mechanisms) variables:

BI: The ratio of outside directors to total directors on the board,

BACT: The ratio of outside directors attending on board meeting to total directors,

AC: An indicator variable equal to 1 if the audit committee exists, otherwise 0.

EA (External Auditor) variable:

BIG: An indicator variable equal to 1 if the firm is audited by a Big 4 accounting firm during the current year, 0 otherwise.

The regression coefficient on the interaction term $\beta_{3}$ in Model (2) provides an estimate of the moderation effect. Thus, if $\beta_{3}$ in Model (2) is statistically different from zero, there is a significant moderation effect on the relation between executive stock options and audit fees in the data. Considering Hypotheses $2 a$ to 4 , we expect that $\beta_{3}$, the coefficients on interaction terms (PESO $\times$ AP (IMM, or EA)), will be statistically significant.

\section{Empirical Results}

\subsection{Descriptive Statistics}

Table 2 shows descriptive statistics on the variables employed in the models.

Table 2. Descriptive statistics.

\begin{tabular}{ccccccc}
\hline Variables & \multicolumn{3}{c}{ Mean } & \multicolumn{3}{c}{ Median } \\
& $\begin{array}{c}\text { with } \\
\text { ESO }\end{array}$ & $\begin{array}{c}\text { without } \\
\text { ESO }\end{array}$ & $\begin{array}{c}\boldsymbol{p} \text {-Value } \\
\text { with } \\
\text { ESO }\end{array}$ & $\begin{array}{c}\text { without } \\
\text { ESO }\end{array}$ & $p$-Value \\
\hline AF (hundred million Korean Won) & 1.79 & 1.200 & 0.000 & 0.898 & 0.8 & 0.001 \\
ESO & 1 & 0 & - & 1 & 0 & - \\
PESO & 0.439 & 0 & - & 0.471 & 0 & - \\
MO & 0.062 & 0.122 & 0.000 & 0.001 & 0.062 & 0.000 \\
CB & 0.480 & 0.250 & 0.000 & 0.000 & 0.000 & 0.000 \\
BI & 0.372 & 0.343 & 0.044 & 0.333 & 0.286 & 0.006 \\
BACT & 0.721 & 0.669 & 0.072 & 0.830 & 0.75 & 0.295 \\
AC & 0.411 & 0.247 & 0.000 & 0.000 & 0.000 & 0.000 \\
BIG & 0.766 & 0.753 & 0.745 & 1.000 & 1.000 & 0.744 \\
REC & 2.740 & 1.660 & 0.010 & 0.420 & 0.236 & 0.701 \\
INV & 0.176 & 0.177 & 0.925 & 0.157 & 0.158 & 0.936 \\
OS & 0.106 & 0.117 & 0.129 & 0.082 & 0.100 & 0.071 \\
SEG & 0.424 & 0.434 & 0.712 & 0.417 & 0.428 & 0.600 \\
LEV & 2.639 & 2.563 & 0.606 & 2.000 & 2.000 & 0.595 \\
ROA & 0.478 & 0.471 & 0.686 & 0.481 & 0.459 & 0.575 \\
LOSS & 0.026 & 0.039 & 0.191 & 0.041 & 0.037 & 0.728 \\
IA & 0.446 & 0.307 & 0.002 & 0.000 & 0.000 & 0.002 \\
NAF & 0.121 & 0.112 & 0.773 & 0.000 & 0.000 & 0.772 \\
& 0.519 & 0.407 & 0.015 & 1.000 & 0.000 & 0.015 \\
\hline
\end{tabular}

Notes: Table 2 reports the descriptive statistics for 462 observations from 110 nonfinancial Korean listed companies, for the period 2000 to 2005 . Two-tailed probability values of the t-test and Mann-Whitney U test can be used to gauge whether there are significant differences in means and medians between the two groups. 
The average (median) of audit fees (AF) for firms with ESO is 1.79 (0.898) hundred million Korean won, while the mean (median) of audit fees for firms without ESO is 1.2 (0.8) hundred million Korean won. Thus, audit fees are significantly higher for firms with ESO than those for firms without ESO. The mean (median) ratio of stock option-based compensation to total executive compensation is 0.439 (0.471). The variables that demonstrate a significant difference between the two groups include $\mathrm{MO}$, $\mathrm{CB}, \mathrm{BI}, \mathrm{AC}, \mathrm{LOSS}$, and NAF.

Table 3 reports the Pearson correlation coefficients of the variables to be used in the research models.

Table 3. Pearson correlation statistics.

Panel A: Correlations among variable LN(AF) to BIG

\begin{tabular}{|c|c|c|c|c|c|c|c|c|c|}
\hline & LN(AF) & ESO & PESO & MO & CB & BI & BACT & AC & BIG \\
\hline $\mathrm{LN}(\mathrm{AF})$ & 1 & & & & & & & & \\
\hline ESO & $0.171^{* * *}$ & 1 & & & & & & & \\
\hline PESO & $0.532^{* * *}$ & - & 1 & & & & & & \\
\hline MO & $-0.351^{* * *}$ & $-0.236^{* * *}$ & $-0.171^{* * *}$ & 1 & & & & & \\
\hline $\mathrm{CB}$ & $0.692 * * *$ & $0.243^{* * *}$ & $0.412^{* * *}$ & $-0.409^{* * *}$ & 1 & & & & \\
\hline BI & 0.632 *** & 0.094 ** & $0.451 * * *$ & $-0.309^{* * *}$ & $0.569^{* * *}$ & 1 & & & \\
\hline BACT & $0.237^{* * *}$ & 0.084 * & $0.392^{* * *}$ & -0.021 & $0.285^{* * *}$ & $0.255^{* * *}$ & 1 & & \\
\hline $\mathrm{AC}$ & $0.737^{* * *}$ & $0.175^{* * *}$ & $0.411^{* * *}$ & $-0.358^{* * *}$ & $0.620 * * *$ & $0.732 * * *$ & $0.276^{* * *}$ & 1 & \\
\hline BIG & $0.416^{* * *}$ & 0.015 & $0.192 * * *$ & -0.013 & $0.330^{* * *}$ & $0.150 * * *$ & $0.132 * * *$ & $0.232^{* * *}$ & 1 \\
\hline LN(TA) & $0.895^{* * *}$ & 0.05 & $0.511^{* * *}$ & $-0.335^{* * *}$ & $0.699 * * *$ & $0.653^{* * *}$ & $0.207^{* * *}$ & $0.753^{* * *}$ & $0.361^{* * *}$ \\
\hline REC & $-0.323^{* * *}$ & -0.004 & -0.055 & $0.144^{* * *}$ & $-0.293^{* * *}$ & $-0.367^{* * *}$ & -0.083 * & $-0.282 * * *$ & $-0.203^{* * *}$ \\
\hline INV & $-0.196^{* * *}$ & -0.071 & $-0.243^{* * *}$ & $0.141^{* * *}$ & $-0.141^{* * *}$ & -0.009 & -0.019 & $-0.183 * * *$ & $-0.197^{* * *}$ \\
\hline OS & $0.198^{* * *}$ & -0.017 & 0.141 * & -0.069 & $0.096^{* *}$ & $0.103^{* *}$ & $0.130 * * *$ & $0.191 * * *$ & -0.067 \\
\hline SEG & $0.584^{* * *}$ & 0.024 & $0.444^{* * *}$ & $-0.238^{* * *}$ & $0.567 * * *$ & $0.444^{* * *}$ & $0.262 * * *$ & $0.574 * * *$ & $0.196^{* * *}$ \\
\hline LEV & $0.184^{* * *}$ & 0.019 & -0.034 & $-0.167^{* * *}$ & $0.131^{* * *}$ & $0.173 * * *$ & 0.049 & $0.230 * * *$ & 0.003 \\
\hline $\mathrm{ROA}$ & $0.154^{* * *}$ & -0.061 & $0.218^{* * *}$ & 0.022 & $0.139^{* * *}$ & $0.095 * *$ & -0.009 & 0.051 & $0.144^{* * *}$ \\
\hline LOSS & -0.038 & $0.143^{* * *}$ & -0.120 * & -0.043 & -0.040 & 0.032 & $0.111^{* *}$ & $0.093 * *$ & -0.065 \\
\hline IA & -0.023 & 0.013 & -0.018 & -0.060 & -0.023 & 0.039 & 0.019 & -0.025 & 0.047 \\
\hline NAF & $0.457 * * *$ & $0.113 * *$ & $0.301 * * *$ & $-0.239^{* * *}$ & $0.345^{* * *}$ & $0.288^{* * *}$ & $0.146^{* * *}$ & $0.375^{* * *}$ & $0.238^{* * *}$ \\
\hline
\end{tabular}

Panel B: Correlations among variable LN(TA) to NAF

\begin{tabular}{|c|c|c|c|c|c|c|c|c|c|c|}
\hline & LN(TA) & REC & INV & OS & SEG & LEV & ROA & LOSS & IA & NAF \\
\hline LN(TA) & 1 & & & & & & & & & \\
\hline REC & $-0.392^{* * *}$ & 1 & & & & & & & & \\
\hline INV & $-0.223^{* * *}$ & 0.023 & 1 & & & & & & & \\
\hline OS & $0.205^{* * *}$ & -0.047 & -0.041 & 1 & & & & & & \\
\hline SEG & $0.594^{* * *}$ & $-0.121^{* * *}$ & -0.047 & $0.294^{* * *}$ & 1 & & & & & \\
\hline LEV & $0.218^{* * *}$ & 0.016 & -0.028 & 0.108 ** & $0.104^{* *}$ & 1 & & & & \\
\hline ROA & $0.192 * * *$ & -0.011 & 0.012 & $-0.113^{* *}$ & $0.149^{* * *}$ & $-0.328^{* * *}$ & 1 & & & \\
\hline LOSS & $-0.125^{* * *}$ & $0.104^{* *}$ & $-0.085^{*}$ & 0.080 * & 0.011 & $0.344^{* * *}$ & $-0.228^{* * *}$ & 1 & & \\
\hline IA & -0.033 & 0.089 * & -0.010 & -0.020 & -0.021 & 0.071 & $0.094^{* *}$ & 0.065 & 1 & \\
\hline NAF & $0.407^{* * *}$ & $-0.101^{* *}$ & $-0.128^{* * *}$ & $0.078^{*}$ & $0.318^{* * *}$ & $0.134^{* * *}$ & $0.107^{* *}$ & 0.013 & $-0.189^{* * *}$ & 1 \\
\hline
\end{tabular}

The ESO (or PESO) is positively correlated with LN(AF). This fact suggests that firms with ESO pay higher audit fees than those without it. While the LN(TA), OS, SEG, LEV, ROA, BIG, and NAF have significantly positive correlations with $\mathrm{LN}(\mathrm{AF})$, the REC and INV have significantly negative correlations with $\mathrm{LN}(\mathrm{AF})$.

\subsection{Relationship between the Existence of ESO and Audit Fees}

In this section, we investigate whether or not there is a significant difference in audit fees between firms with ESO and those without it. Model 1 in Table 4 is a multiple regression model that controls the variables representing audit effort, complexity and risk factors, while Model 2 controls the variables representing characteristics of external auditors, in addition to control variables included in Model 1.

$$
\begin{aligned}
& \mathrm{LN}(\mathrm{AF})_{\mathrm{i}, \mathrm{t}}=\alpha+\beta_{1} \mathrm{ESO}_{\mathrm{i}, \mathrm{t}}+\beta_{2} \mathrm{LN}(\mathrm{TA})_{\mathrm{i}, \mathrm{t}}+\beta_{3} \mathrm{REC}_{\mathrm{i}, \mathrm{t}}+\beta_{4} \mathrm{INV}_{\mathrm{i}, \mathrm{t}}+\beta_{5} \mathrm{OS}_{\mathrm{i}, \mathrm{t}}+\beta_{6} \mathrm{SEG}_{\mathrm{i}, \mathrm{t}}+ \\
& \beta_{7} \mathrm{LEV}_{\mathrm{i}, \mathrm{t}}+\beta_{8} \mathrm{ROA}_{\mathrm{i}, \mathrm{t}}+\beta_{9} \mathrm{LOSS}_{\mathrm{i}, \mathrm{t}}+\beta_{10} \mathrm{BIG}_{\mathrm{i}, \mathrm{t}}+\beta_{11} \mathrm{IA}_{\mathrm{i}, \mathrm{t}}+\beta_{12} \mathrm{NAF}_{\mathrm{i}, \mathrm{t}}+\beta_{\mathrm{i}} \mathrm{IND}_{\mathrm{i}}+\beta_{\mathrm{t}} \mathrm{YEAR}_{\mathrm{t}}+\varepsilon_{\mathrm{i}, \mathrm{t}}
\end{aligned}
$$


Table 4. Relationship between the existence of ESO and audit fees.

\begin{tabular}{|c|c|c|c|c|}
\hline \multirow{3}{*}{$\begin{array}{l}\text { Independent } \\
\text { Variables }\end{array}$} & \multicolumn{4}{|c|}{ Dependent Variable: LN(AF) } \\
\hline & \multicolumn{2}{|c|}{ Model 1} & \multicolumn{2}{|c|}{ Model 2} \\
\hline & Coefficient & t-Value & Coefficient & t-Value \\
\hline Constant & 6.539 & $16.804^{* * *}$ & 7.077 & $18.569 * * *$ \\
\hline ESO & 0.197 & $5.774^{* * *}$ & 0.185 & $5.675^{* * *}$ \\
\hline LN(TA) & 0.434 & $29.157^{* * *}$ & 0.405 & $27.294^{* * *}$ \\
\hline REC & 0.218 & 1.166 & 0.258 & 1.438 \\
\hline INV & 0.171 & 0.786 & 0.361 & $1.728^{*}$ \\
\hline OS & -0.006 & -0.088 & 0.046 & 0.759 \\
\hline SEG & 0.036 & $2.580^{* * *}$ & 0.028 & $2.135^{* *}$ \\
\hline LEV & -0.213 & $-1.956 *$ & -0.224 & $-2.143^{* *}$ \\
\hline ROA & -0.153 & -0.863 & -0.254 & -1.483 \\
\hline LOSS & 0.115 & $2.958^{* * *}$ & 0.109 & $2.920 * * *$ \\
\hline BIG & & & 0.214 & $5.157^{* * *}$ \\
\hline IA & & & 0.039 & 0.749 \\
\hline NAF & & & 0.144 & $3.929^{* * *}$ \\
\hline F-Value & \multicolumn{2}{|c|}{$237.016^{* * *}$} & \multicolumn{2}{|c|}{$199.415^{* * *}$} \\
\hline Adj. $\mathrm{R}^{2}$ & \multicolumn{2}{|c|}{0.822} & \multicolumn{2}{|c|}{0.839} \\
\hline
\end{tabular}

Notes: Table 4 presents the test results for the relation between the existence of ESO and audit fees. Model 1 in Table 4 is a multiple regression model that controls the variables representing audit effort, complexity, and risk factors, while Model 2 controls the variables representing characteristics of external auditors, in addition to control variables included in Model 1. ${ }^{* * *}, * *$, and ${ }^{*}$ indicate significance at $1 \%, 5 \%$, and $10 \%$, respectively. Estimated coefficients for industry and year dummy variables are not reported for brevity.

The empirical results of Models 1 and 2 in Table 4 show that the presence of ESO is positively related to audit fees in each model. These results support Hypothesis 1a that audit fees for a firm granting ESO are higher than those for a firm without it. Therefore, this finding indicates that the existence of ESO leads to an increase in audit risk, which results in higher audit fees, demanded by the auditor to compensate for increase in audit risk.

Consistent with prior studies, firm size, number of segments, and negative earnings have significantly positive effects on audit fees in Model 1 [30,43,44]. In Model 2, audit fees are also significantly higher for clients who employ a big auditing firm and get non-audit services from their external auditors. However, the ratio of liabilities to total assets has a negative effect on audit fees, which is inconsistent with our expectations.

\subsection{Relationship between the Portions of ESO to Total Executive Compensation and Audit Fees}

In this section, focusing on the firms with ESO, we investigate the effect of the portion of ESO to total executive compensation on audit fees. Table 5 shows that the portions of ESO to total executive compensation have significantly positive impacts on audit fees in both Models 3 and 4 . These results in Table 5 demonstrate that the increase in the portion of ESO to total executive compensation leads to higher audit risk and, thus, higher audit fees. Among the control variables in Model 3, firm size, the ratio of inventories to total assets, and loss dummy have significantly positive effects on audit fees. Further, in Model 4, audit fees are significantly higher for clients who employ a big auditing firm and buy non-audit services from their external auditor. However, the ratio of debt to total assets has a significantly negative effect on audit fees.

$$
\begin{aligned}
& \mathrm{LN}(\mathrm{AF})_{i, \mathrm{t}}=\alpha+\beta_{1} \mathrm{PESO}_{\mathrm{i}, \mathrm{t}}+\beta_{2} \mathrm{LN}(\mathrm{TA})_{i, \mathrm{t}}+\beta_{3} \mathrm{REC}_{\mathrm{i}, \mathrm{t}}+\beta_{4} \mathrm{INV}_{\mathrm{i}, \mathrm{t}}+\beta_{5} \mathrm{OS}_{\mathrm{i}, \mathrm{t}}+\beta_{6} \mathrm{SEG}_{\mathrm{i}, \mathrm{t}}+ \\
& \beta_{7} \mathrm{LEV}_{\mathrm{i}, \mathrm{t}}+\beta_{8} \mathrm{ROA}_{\mathrm{i}, \mathrm{t}}+\beta_{9} \mathrm{LOSS}_{\mathrm{i}, \mathrm{t}}+\beta_{10} \mathrm{BIG}_{\mathrm{i}, \mathrm{t}}+\beta_{11} \mathrm{IA}_{\mathrm{i}, \mathrm{t}}+\beta_{12} \mathrm{NAF}_{\mathrm{i}, \mathrm{t}}+\beta_{\mathrm{i}} \mathrm{IND}_{\mathrm{i}}+\beta_{\mathrm{t}} \mathrm{YEAR}_{\mathrm{t}}+\varepsilon_{\mathrm{i}, \mathrm{t}}
\end{aligned}
$$


Table 5. Relationship between the portion of ESO to total executive compensation and audit fees.

\begin{tabular}{|c|c|c|c|c|}
\hline \multirow{3}{*}{$\begin{array}{l}\text { Independent } \\
\text { Variables }\end{array}$} & \multicolumn{4}{|c|}{ Dependent Variable: LN(AF) } \\
\hline & \multicolumn{2}{|c|}{ Model 3} & \multicolumn{2}{|c|}{ Model 4} \\
\hline & Coefficient & t-Value & Coefficient & t-Value \\
\hline Constant & 6.275 & $11.357^{* * *}$ & 7.182 & $13.046^{* * *}$ \\
\hline PESO & 0.178 & $2.097 * *$ & 0.188 & $2.339 * *$ \\
\hline LN(TA) & 0.450 & $20.870^{* * *}$ & 0.409 & $18.523^{* * *}$ \\
\hline REC & 0.224 & 0.914 & 0.129 & 0.553 \\
\hline INV & 0.580 & $1.930 *$ & 0.545 & $1.922 *$ \\
\hline OS & 0.115 & 1.403 & 0.136 & $1.753 *$ \\
\hline SEG & 0.027 & 1.403 & 0.013 & 0.694 \\
\hline LEV & -0.467 & $-3.028^{* * *}$ & -0.337 & $-2.262 * *$ \\
\hline $\mathrm{ROA}$ & -0.459 & -1.628 & -0.484 & $-1.802 *$ \\
\hline LOSS & 0.105 & $2.129 * *$ & 0.085 & $1.818^{*}$ \\
\hline BIG & & & 0.107 & 1.957 * \\
\hline IA & & & 0.003 & 0.041 \\
\hline NAF & & & 0.242 & $4.809 * * *$ \\
\hline F-value & \multicolumn{2}{|c|}{$173.256^{* * *}$} & \multicolumn{2}{|c|}{$148.388^{* * *}$} \\
\hline Adj. $\mathrm{R}^{2}$ & \multicolumn{2}{|c|}{0.871} & \multicolumn{2}{|c|}{0.885} \\
\hline
\end{tabular}

Notes: Table 5 presents the test results for the association between the portions of ESO to total executive compensation and audit fees. Model 3 in Table 5 is a multiple regression model that controls the variables representing audit effort, complexity, and risk factors, while Model 4 controls the variables representing characteristics of external auditors, in addition to control variables included in Model 3. ${ }^{* * *},{ }^{* *}$, and ${ }^{*}$ indicate significance at $1 \%, 5 \%$, and $10 \%$, respectively. Estimated coefficients for industry and year dummy variables are not reported for brevity.

\subsection{Moderating Effects of Agency Problems on the Relationship between the Portions of ESO to Total Executive Compensation and Audit Fees}

This section examines the influence that agency problems have on the relationship between the portion of stock option-based compensation to total executive compensation and audit fees. Thus, we consider two types of agency problems. One is the traditional agency problems between shareholders and management [20], and the other is the agency problems with focus on the conflict between majority and minority owners [63]. We used the interaction terms of the portion of ESO to total executive compensation with agency problem variables as additional independent variables to predict the moderating effect of agency problems on the relationship between the portion of ESO and audit fees. Table 6 summarizes our empirical test results.

$$
\begin{aligned}
& \mathrm{LN}(\mathrm{AF})_{\mathrm{i}, \mathrm{t}}=\alpha+\beta_{1} \mathrm{PESO}_{\mathrm{i}, \mathrm{t}}+\beta_{2} \mathrm{MO}_{\mathrm{i}, \mathrm{t}}\left[\mathrm{CB}_{\mathrm{i}, \mathrm{t}}\right]+\beta_{3} \mathrm{PESO}_{\mathrm{i}, \mathrm{t}} \times \mathrm{MO}_{\mathrm{i}, \mathrm{t}}\left[\mathrm{PESO}_{\mathrm{i}, \mathrm{t}} \times \mathrm{CB}_{\mathrm{i}, \mathrm{t}}\right]+ \\
& \beta_{4} \mathrm{LN}(\mathrm{TA})_{\mathrm{i}, \mathrm{t}}+\beta_{5} \mathrm{REC}_{\mathrm{i}, \mathrm{t}}+\beta_{6} \mathrm{INV}_{\mathrm{i}, \mathrm{t}}+\beta_{7} \mathrm{OS}_{\mathrm{i}, \mathrm{t}}+\beta_{8} \mathrm{SEG}_{\mathrm{i}, \mathrm{t}}+\beta_{9} \mathrm{LEV}_{\mathrm{i}, \mathrm{t}}+\beta_{10} \mathrm{ROA}_{\mathrm{i}, \mathrm{t}}+\beta_{11} \mathrm{LOSS}_{\mathrm{i}, \mathrm{t}} \\
& +\beta_{12} \mathrm{BIG}_{\mathrm{i}, \mathrm{t}}+\beta_{13} \mathrm{IA}_{\mathrm{i}, \mathrm{t}}+\beta_{14} \mathrm{NAF}_{\mathrm{i}, \mathrm{t}}+\beta_{\mathrm{i}} \mathrm{IND}_{\mathrm{i}}+\beta_{\mathrm{t}} \mathrm{YEAR}_{, \mathrm{t}}+\varepsilon_{\mathrm{i}, \mathrm{t}}
\end{aligned}
$$

Using Model 5 in Table 6, we ran the regression analysis, showing the moderating effect of management ownership on the association between the portion of ESO to total compensation and audit fees. As can be seen in Table 6, the coefficient on the interaction term of the portion of ESO to total executive compensation with management ownership is significantly negative. This empirical result supports our Hypothesis $2 \mathrm{a}$ that the effect of ESO on audit fees is higher for firms with non-owner managers than that for firms with owner managers.

Model 6 of Table 6 provides the result of the regression analysis, testing the moderating effect of conglomerate-affiliated companies on the association between the portion of ESO to total executive compensation and audit fees. According to the test result from Model 6, the coefficient on the interaction term of the portion of ESO to total executive compensation with conglomerate-affiliated companies is positive and statistically significant. This result supports Hypothesis $2 b$ that the effect of ESO on audit fees is higher for firms belonging to a conglomerate called Chaebol in Korea. These 
statistical test results in Table 6 help to prove the suggestion that higher agency problems can raise audit risk, resulting in higher audit fees.

Table 6. Moderating effects of agency problems on the telationship between the portion of ESO to total executive compensation and audit fees.

\begin{tabular}{|c|c|c|c|c|}
\hline \multirow{3}{*}{$\begin{array}{l}\text { Independent } \\
\text { Variables }\end{array}$} & \multicolumn{4}{|c|}{ Dependent Variable: LN(AF) } \\
\hline & \multicolumn{2}{|c|}{ Model 5} & \multicolumn{2}{|c|}{ Model 6} \\
\hline & Coefficient & t-Value & Coefficient & t-Value \\
\hline Constant & 7.054 & $12.407^{* * *}$ & 7.273 & $12.090 * * *$ \\
\hline PESO & 0.303 & $3.220^{* * *}$ & -0.073 & -0.651 \\
\hline $\mathrm{MO}$ & 1.186 & $3.132 * * *$ & & \\
\hline $\mathrm{PESO} \times \mathrm{MO}$ & -1.828 & $-2.426^{* *}$ & & \\
\hline $\mathrm{CB}$ & & & -0.248 & $-2.846^{* * *}$ \\
\hline $\mathrm{PESO} \times \mathrm{CB}$ & & & 0.500 & $3.267^{* * *}$ \\
\hline LN(TA) & 0.409 & $17.938^{* * *}$ & 0.411 & $17.145^{* * *}$ \\
\hline REC & 0.081 & 0.351 & 0.154 & 0.676 \\
\hline INV & 0.395 & 1.397 & 0.340 & 1.197 \\
\hline OS & 0.125 & 1.636 & 0.075 & 0.965 \\
\hline SEG & 0.015 & 0.812 & 0.016 & 0.841 \\
\hline LEV & -0.257 & $-1.713 *$ & -0.349 & $-2.381 * *$ \\
\hline $\mathrm{ROA}$ & -0.487 & $-1.824 *$ & -0.581 & $-2.197^{* *}$ \\
\hline LOSS & 0.089 & 1.938 * & 0.077 & $1.673 *$ \\
\hline BIG & 0.107 & $1.95 *$ & 0.100 & 1.880 * \\
\hline IA & 0.018 & 0.272 & 0.001 & 0.008 \\
\hline NAF & 0.251 & $5.023^{* * *}$ & 0.245 & $4.925^{* * *}$ \\
\hline F-value & \multicolumn{2}{|c|}{$132.447^{* * * *}$} & \multicolumn{2}{|c|}{$133.579^{* * *}$} \\
\hline Adj. $R^{2}$ & \multicolumn{2}{|c|}{0.889} & \multicolumn{2}{|c|}{0.890} \\
\hline
\end{tabular}

Notes: Table 6 presents the test results for moderating effects of agency problems on the relationship between the portions of ESO to total executive compensation and audit fees. Model 5 in Table 6 shows the result of the regression analysis, testing the moderating effect of management ownership on the association between the portion of ESO to total compensation and audit fees. Model 6 of Table 6 provides the result of the regression analysis, testing the moderating effect of conglomerate-affiliated companies on the association between the portion of ESO to total executive compensation and audit fees. $* * * * *$, and $*$ indicate significance at $1 \%, 5 \%$, and $10 \%$, respectively. Estimated coefficients for industry and year dummy variables are not reported for brevity.

4.5. Moderating Effects of Internal Monitoring Mechanisms on the Relationship between the Portions of ESO to Total Executive Compensation and Audit Fees

This section investigates the influence that internal monitoring mechanisms have on the relationship between the portion of ESO to total executive compensation and audit fees. In this section, we regarded three variables, such as the proportion of outside directors on the board, the rate of attendance by outside directors at the board, and the existence of audit committees on the board as proxies for effective internal monitoring systems. Table 7 contains the statistical test results that an internal monitoring mechanism influences on the relationship between the portion of ESO to total executive compensation and audit fees.

$$
\begin{aligned}
& \mathrm{LN}(\mathrm{AF})_{\mathrm{i}, \mathrm{t}}=\alpha+\beta_{1} \mathrm{PESO}_{\mathrm{i}, \mathrm{t}}+\beta_{2} \mathrm{BI}_{\mathrm{i}, \mathrm{t}}\left[\mathrm{BACT}_{\mathrm{i}, \mathrm{t}} \text { or } \mathrm{AC}_{\mathrm{i}, \mathrm{t}}\right]+\beta_{3} \mathrm{PESO}_{\mathrm{i}, \mathrm{t}} \times \mathrm{BI}_{\mathrm{i}, \mathrm{t}} \mathrm{PESO}_{\mathrm{i}, \mathrm{t}} \times \mathrm{BACT}_{\mathrm{i}, \mathrm{t}} \\
& \text { or PESO } \left._{\mathrm{i}, \mathrm{t}} \times \mathrm{AC}_{\mathrm{i}, \mathrm{t}}\right]+\beta_{4} \mathrm{LN}(\mathrm{TA})_{\mathrm{i}, \mathrm{t}}+\beta_{5} \mathrm{REC}_{\mathrm{i}, \mathrm{t}}+\beta_{6} \mathrm{INV}_{\mathrm{i}, \mathrm{t}}+\beta_{7} \mathrm{OS}_{\mathrm{i}, \mathrm{t}}+\beta_{8} \mathrm{SEG}_{\mathrm{i}, \mathrm{t}}+\beta_{9} \mathrm{LEV}_{\mathrm{i}, \mathrm{t}} \\
& +\beta_{10} \mathrm{ROA}_{\mathrm{i}, \mathrm{t}}+\beta_{11} \mathrm{LOSS}_{\mathrm{i}, \mathrm{t}}+\beta_{12} \mathrm{BIG}_{\mathrm{t}}+\beta_{13} \mathrm{IA}_{\mathrm{i}, \mathrm{t}}+\beta_{14} \mathrm{NAF}_{\mathrm{i}, \mathrm{t}}+\beta_{\mathrm{i}} \mathrm{IND}_{\mathrm{i}}+\beta_{\mathrm{t}} \mathrm{YEAR}_{\mathrm{t}}+\varepsilon_{\mathrm{i}, \mathrm{t}}
\end{aligned}
$$


Table 7. Moderating effects of internal monitoring mechanisms on the relationship between the portion of ESO to total executive compensation and audit fees.

\begin{tabular}{|c|c|c|c|c|c|c|}
\hline \multirow{3}{*}{$\begin{array}{l}\text { Independent } \\
\text { Variables }\end{array}$} & \multicolumn{6}{|c|}{ Dependent Variable: LN(AF) } \\
\hline & \multicolumn{2}{|c|}{ Model 7} & \multicolumn{2}{|c|}{ Model 8} & \multicolumn{2}{|c|}{ Model 9} \\
\hline & Coefficient & t-Value & Coefficient & t-Value & Coefficient & t-Value \\
\hline Constant & 7.965 & $13.761^{* * *}$ & 7.266 & $13.011^{* * *}$ & 8.653 & $13.579 * * *$ \\
\hline PESO & -0.175 & -0.908 & -0.220 & -0.986 & 0.073 & 0.726 \\
\hline BI & 0.218 & 0.743 & & & & \\
\hline $\mathrm{PESO} \times \mathrm{BI}$ & 0.795 & $1.762 *$ & & & & \\
\hline BACT & & & -0.406 & $-3.287^{* * *}$ & & \\
\hline $\mathrm{PESO} \times \mathrm{BACT}$ & & & 0.597 & $2.175 * *$ & & \\
\hline $\mathrm{AC}$ & & & & & 0.186 & 1.934 * \\
\hline $\mathrm{PESO} \times \mathrm{AC}$ & & & & & 0.245 & 1.680 * \\
\hline LN(TA) & 0.375 & $15.662 * * *$ & 0.414 & $18.607^{* * *}$ & 0.353 & $13.926^{* * *}$ \\
\hline REC & 0.270 & 1.166 & 0.051 & 0.217 & 0.257 & 1.134 \\
\hline INV & 0.456 & 1.642 & 0.541 & $1.881 *$ & 0.553 & $1.998^{* *}$ \\
\hline OS & 0.092 & 1.195 & 0.157 & $2.016^{* *}$ & 0.067 & 0.871 \\
\hline SEG & 0.015 & 0.853 & 0.011 & 0.587 & 0.001 & 0.074 \\
\hline LEV & -0.242 & -1.632 & -0.320 & $-2.160^{* *}$ & -0.321 & $-2.230 * *$ \\
\hline $\mathrm{ROA}$ & -0.336 & -1.262 & -0.448 & $-1.667 *$ & -0.334 & -1.261 \\
\hline LOSS & 0.058 & 1.257 & 0.100 & $2.119 * *$ & 0.031 & 0.661 \\
\hline BIG & 0.131 & $2.422 * *$ & 0.138 & $2.460 * *$ & 0.108 & $2.063^{* *}$ \\
\hline IA & -0.024 & -0.371 & -0.005 & -0.082 & -0.006 & -0.096 \\
\hline NAF & 0.250 & $5.088^{* * *}$ & 0.241 & $4.832^{* * *}$ & 0.240 & $4.957^{* * * *}$ \\
\hline F-value & \multicolumn{2}{|c|}{$134.690 * * *$} & \multicolumn{2}{|c|}{$126.843^{* * *}$} & \multicolumn{2}{|c|}{$138.355^{* * *}$} \\
\hline Adj. $\mathrm{R}^{2}$ & \multicolumn{2}{|c|}{0.891} & \multicolumn{2}{|c|}{0.886} & \multicolumn{2}{|c|}{0.893} \\
\hline
\end{tabular}

Notes: Table 7 presents the test results for moderating effects of internal monitoring mechanisms on the relationship between the portions of ESO to total executive compensation and audit fees. Model 7 in Table 7 shows the result of the regression analysis, testing the moderating effect of the percentage of outside directors on the board on the association between the portion of ESO to total compensation and audit fees. Model 8 of Table 7 provides the result of the regression analysis, testing the moderating effect of the attendance rate of outside directors at board meetings on the association between the portion of ESO to total executive compensation and audit fees. Model 9 of Table 7 presents the result of the regression analysis, testing the moderating effect of the existence of audit committees on the board on the association between the portion of ESO to total executive compensation and audit fees. ***,**, and ${ }^{*}$ indicate significance at $1 \%, 5 \%$, and $10 \%$, respectively. Estimated coefficients for industry and year dummy variables are not reported for brevity.

As can be seen in Table 7, all coefficients on the interaction terms of the portion of ESO to total executive compensation with internal monitoring variables such as the percentage of outside directors on the board, the attendance rate of outside directors at board meetings, and the existence of audit committees on the board are significantly positive. These test results support the hypothesis $3 \mathrm{a}, 3 \mathrm{~b}$ and $3 c$ that the effect of the portion of ESO to total executive compensation on audit fees is higher for firms with more effective internal monitoring mechanisms. These results also imply that internal monitoring systems and external auditing are complements, not substitutes. In other words, when the boards include more independent outside directors and when outside directors participate more actively in the board meetings, the boards demand an even higher quality of audit services. In addition, when audit committees responsible for securing reliable financial reporting exist on the board, they are likely to employ high-quality external auditors.

\subsection{Moderating Effect of Big Accounting Firms on the Relationship between the Portions of ESO to Total Executive Compensation and Audit Fees}

In this section, we empirically test the effect of big audit firms on the relationship between the portion of ESO to total executive compensation and audit fees. Table 8 reports our empirical test results. 


$$
\begin{aligned}
& \text { LN(AF) })_{i, t}=\alpha+\beta_{1} \text { PESO }_{i, t}+\beta_{2} \text { BIG }_{i, t}+\beta_{3} \text { PESO } \times \text { BIG }_{i, t}+\beta_{4} \mathrm{LN}(\mathrm{TA})_{i, \mathrm{t}}+\beta_{5} \mathrm{REC}_{\mathrm{i}, \mathrm{t}}+\beta_{6} \mathrm{INV}_{\mathrm{i}, \mathrm{t}} \\
& +\beta_{7} \mathrm{OS}_{\mathrm{i}, \mathrm{t}}+\beta_{8} \mathrm{SEG}_{\mathrm{i}, \mathrm{t}}+\beta_{9} \mathrm{LEV}_{\mathrm{i}, \mathrm{t}}+\beta_{10} \mathrm{ROA}_{\mathrm{i}, \mathrm{t}}+\beta_{11} \mathrm{LOSS}_{\mathrm{i}, \mathrm{t}}+\beta_{12} \mathrm{IA}_{\mathrm{i}, \mathrm{t}} \\
& +\beta_{13} \mathrm{NAF}_{\mathrm{i}, \mathrm{t}}+\beta_{\mathrm{i}} \mathrm{IND}_{\mathrm{i}}+\beta_{\mathrm{t}} \mathrm{YEAR}_{\mathrm{t}, \mathrm{t}}+\varepsilon_{\mathrm{i}, \mathrm{t}}
\end{aligned}
$$

Table 8. Moderating Effect of Big Accounting Firms on the Relationship between the Portion of ESO to Total Executive Compensation and Audit Fees.

\begin{tabular}{ccc}
\hline \multirow{2}{*}{ Independent Variables } & \multicolumn{2}{c}{ Dependent Variable: LN(AF) } \\
\cline { 2 - 3 } & \multicolumn{2}{c}{ Model 10 } \\
\cline { 2 - 3 } & Coefficient & t-Value \\
\hline Constant & 7.420 & $13.836^{* * *}$ \\
PESO & -0.362 & $-2.274^{* *}$ \\
BIG & -0.139 & $-1.709^{*}$ \\
PESO $\times$ BIG & 0.713 & $3.959^{* * *}$ \\
LN(TA) & 0.411 & $19.221^{* * *}$ \\
REC & 0.029 & 0.127 \\
INV & 0.409 & 1.480 \\
OS & 0.067 & 0.870 \\
SEG & 0.014 & 0.793 \\
LEV & -0.407 & $-2.795^{* * *}$ \\
ROA & -0.567 & $-2.172^{* *}$ \\
LOSS & 0.097 & $2.127^{* * *}$ \\
IA & -0.003 & -0.042 \\
NAF & 0.186 & $3.684^{* * *}$ \\
\hline F-value & \multicolumn{2}{c}{$147.398^{* * *}$} \\
Adj. $R^{2}$ & 0.892 \\
\hline
\end{tabular}

Notes: The Model 10 of Table 8 presents the test results for moderating effect of big accounting firms on the relationship between the portions of ESO to total executive compensation and audit fees. ${ }^{* * *}, * *$, and ${ }^{*}$ indicate significance at $1 \%, 5 \%$ and $10 \%$, respectively. Estimated coefficients for industry and year dummy variables are not reported for brevity.

As seen in Table 8, we found that the coefficient on the interaction term of the portion of ESO to total compensation with big auditing firms is significantly positive. This empirical result supports our Hypothesis 4 that the effect of the portion of ESO to total executive compensation on audit fees is higher for firms employing big accounting firms.

\subsection{Robustness Checks}

\subsubsection{Test Results Using Additional Independent Variables}

In this subsection, in order to justify our measurement of the portion of ESO to total executive compensation (PESO) as an independent variable, we ran an additional analysis, replacing the ratio of the number of unvested ESO with the number of granted ESO (NESO) and the ratio of the number of unvested ESO with the number of granted ESO and shares (NESOS). At the same time, we tested a model with the ESO incentive distinguished as price incentive (DELTA) and risk incentive (VEGA) as additional control variables to determine the independent impact of the portion of ESO to total executive compensation on the audit fees (Whereas VEGA represents the change in the manager's wealth to stock price volatility in dollar amounts, DELTA shows the change in the manager's wealth to stock price itself in dollar amounts.). The results are presented in Table 9.

$$
\begin{aligned}
& \left.\mathrm{LN}(\mathrm{AF})_{i, \mathrm{t}}=\alpha+\beta_{1} \mathrm{NESO}_{\mathrm{i}, \mathrm{t}} \mathrm{NESOS}_{\mathrm{i}, \mathrm{t}}\right]+\beta_{2} \mathrm{LN}(\mathrm{TA})_{\mathrm{i}, \mathrm{t}}+\beta_{3} \mathrm{REC}_{\mathrm{i}, \mathrm{t}}+\beta_{4} \mathrm{INV}_{\mathrm{i}, \mathrm{t}}+\beta_{5} \mathrm{OS}_{\mathrm{i}, \mathrm{t}}+ \\
& \beta_{6} \mathrm{SEG}_{\mathrm{i}, \mathrm{t}}+\beta_{7} \mathrm{LEV}_{\mathrm{i}, \mathrm{t}}+\beta_{8} \mathrm{ROA}_{\mathrm{i}, \mathrm{t}}+\beta_{9} \mathrm{LOSS}_{\mathrm{i}, \mathrm{t}}+\beta_{10} \mathrm{BIG}_{\mathrm{i}, \mathrm{t}}+\beta_{11} \mathrm{IA}_{\mathrm{i}, \mathrm{t}}+\beta_{12} \mathrm{NAF}_{\mathrm{i}, \mathrm{t}} \\
& +\beta_{\mathrm{i}} \mathrm{IND}_{\mathrm{i}}+\beta_{\mathrm{t}} \mathrm{YEAR}_{\mathrm{t}}+\varepsilon_{\mathrm{i}, \mathrm{t}}
\end{aligned}
$$


$\mathrm{LN}(\mathrm{AF})_{\mathrm{i}, \mathrm{t}}=\alpha+\beta_{1} \mathrm{PESO}_{\mathrm{i}, \mathrm{t}}+\beta_{2} \mathrm{DELTA}_{\mathrm{i}, \mathrm{t}}+\beta_{3} \mathrm{VEGA}_{\mathrm{i}, \mathrm{t}}+\beta_{4} \mathrm{LN}(\mathrm{TA})_{\mathrm{i}, \mathrm{t}}+\beta_{5} \mathrm{REC}_{\mathrm{i}, \mathrm{t}}+\beta_{6} \mathrm{INV}_{\mathrm{i}, \mathrm{t}}$

$+\beta_{7} \mathrm{OS}_{\mathrm{i}, \mathrm{t}}+\beta_{8} \mathrm{SEG}_{\mathrm{i}, \mathrm{t}}+\beta_{9} \mathrm{LEV}_{\mathrm{i}, \mathrm{t}}+\beta_{10} \mathrm{ROA}_{\mathrm{i}, \mathrm{t}}+\beta_{11} \mathrm{LOSS}_{\mathrm{i}, \mathrm{t}}+\beta_{12} \mathrm{BIG}_{\mathrm{i}, \mathrm{t}}$

$+\beta_{13} \mathrm{IA}_{\mathrm{i}, \mathrm{t}}+\beta_{14} \mathrm{NAF}_{\mathrm{i}, \mathrm{t}}+\beta_{\mathrm{i}} \mathrm{IND}_{\mathrm{i}}+\beta_{\mathrm{t}} \mathrm{YEAR}_{, \mathrm{t}}+\varepsilon_{\mathrm{i}, \mathrm{t}}$

Table 9. Test results using additional independent variables.

\begin{tabular}{|c|c|c|c|c|c|c|}
\hline \multirow{3}{*}{$\begin{array}{l}\text { Independent } \\
\text { Variables }\end{array}$} & \multicolumn{6}{|c|}{ Dependent Variable: LN(AF) } \\
\hline & \multicolumn{2}{|c|}{ Model 11} & \multicolumn{2}{|c|}{ Model 12} & \multicolumn{2}{|c|}{ Model 13} \\
\hline & Coefficient & t-Value & Coefficient & t-Value & Coefficient & t-Value \\
\hline Constant & 17.831 & $127.137 * * *$ & 7.020 & $16.443^{* * *}$ & 7.380 & $12.234^{* * *}$ \\
\hline PESO & & & & & 0.220 & $2.323^{* *}$ \\
\hline NESO & 3.648 & $5.651^{* * *}$ & & & & \\
\hline NESOS & & & 0.186 & $4.054^{* * *}$ & & \\
\hline DELTA & & & & & 0.990 & 1.759 * \\
\hline VEGA & & & & & -0.980 & -1.269 \\
\hline LN(TA) & 5.396 & $5.491^{* * *}$ & 0.408 & $24.792^{* * *}$ & 0.405 & $16.836^{* * *}$ \\
\hline REC & 1.241 & $4.234^{* * *}$ & 0.353 & $1.824 *$ & 0.116 & 0.425 \\
\hline INV & 1.338 & $3.616^{* * *}$ & 0.453 & $1.920 *$ & 0.322 & 0.974 \\
\hline OS & 0.027 & 0.252 & -0.109 & -1.606 & 0.117 & 1.258 \\
\hline SEG & 0.195 & $9.064^{* * *}$ & 0.033 & $2.222 * *$ & 0.007 & 0.318 \\
\hline LEV & 0.641 & $3.913^{* * *}$ & -0.180 & $-1.671 *$ & -0.571 & $-3.239 * *$ \\
\hline $\mathrm{ROA}$ & 0.473 & 1.609 & -0.308 & $-1.699 *$ & -0.539 & -1.759 * \\
\hline LOSS & -1.112 & -1.839 * & 0.122 & $3.075^{* * *}$ & 0.035 & 0.622 \\
\hline BIG & 0.331 & $4.499^{* * *}$ & 0.160 & $3.479 * * *$ & 0.123 & 1.902 * \\
\hline IA & 0.014 & 0.159 & 0.051 & 0.917 & -0.050 & -0.637 \\
\hline NAF & 0.384 & $6.023^{* * *}$ & 0.199 & $4.900^{* * *}$ & 0.283 & $4.695^{* * *}$ \\
\hline F-value & \multicolumn{2}{|c|}{$50.068^{* * *}$} & \multicolumn{2}{|c|}{$172.071^{* * *}$} & \multicolumn{2}{|c|}{82.239 *** } \\
\hline Adj. $R^{2}$ & \multicolumn{2}{|c|}{0.808} & \multicolumn{2}{|c|}{0.844} & \multicolumn{2}{|c|}{0.880} \\
\hline
\end{tabular}

Notes: Table 9 presents a series of robustness checks. Model 11 in Table 9 shows the result of the regression analysis, testing the association between the ratio of the number of unvested ESO to the number of granted ESO (NESO) and audit fees. Model 12 in Table 9 displays the result of the regression analysis, testing the association between the ratio of the number of unvested ESO to the number of granted ESO and shares (NESOS) and audit fees. Model 13 in Table 9 shows the result of the regression model with the ESO incentive distinguished as price incentive (DELTA) and risk incentive (VEGA) as additional control variables. ${ }^{* * *}, * *$, and $*$ indicate significance at $1 \%, 5 \%$, and $10 \%$, respectively. Estimated coefficients for industry and year dummy variables are not reported for brevity.

In both Models 11 and 12 of Table 9, the estimated coefficients on the ratio of the number of unvested ESO to the number of granted ESO (NESO) and the ratio of the number of unvested ESO to the number of granted ESO and shares (NESOS) are significantly positive. In addition, after controlling for the effect of ESO incentive on audit quality, we found that the portion of ESO to total executive compensation (PESO) is positively related to audit fees in Model 13 of Table 9. Among the additional control variables, we found that delta is positively related to audit fees in Model 13, but vega isn't. These results uncover that delta is more important incentive factor than vaga. In sum, these empirical results presented in this section confirm that ESO is positively related to audit fees.

4.7.2. Test Results Using Market-to-Book Value and Market Value of the Firm as Additional Control Variables

Firms with higher market-to-book value or market value tend to have much more aggressive stock option programs, as evidenced by consistently higher flows of new stock option grants [64-66]. Therefore, to control for the impact of market-to-book value or market value of the firm on audit fees, we used the market-to-book value and market value of the firm as additional control variables. We measured the market-to-book value as the value of the market value of the equity divided by the book value of the equity. We also measured the market value of the firm as the market value of the equity. Table 10 reports the test results of the robustness check of findings using the market-to-book value and market value of the firm as additional control variables. While Model 14 in Table 10 presents test 
results on the relationship between the existence of ESO and audit fees, Model 15 in Table 10 shows the test results on the effect of the portion of ESO to total executive compensation on audit fees.

$$
\begin{aligned}
& \mathrm{LN}(\mathrm{AF})_{\mathrm{i}, \mathrm{t}}=\alpha+\beta_{1} \mathrm{ESO}_{\mathrm{i}, \mathrm{t}}\left[\mathrm{PESO}_{\mathrm{i}, \mathrm{t}}\right]+\beta_{2} \mathrm{LN}(\mathrm{TA})_{\mathrm{i}, \mathrm{t}}+\beta_{3} \mathrm{REC}_{\mathrm{i}, \mathrm{t}}+\beta_{4} \mathrm{INV}_{\mathrm{i}, \mathrm{t}}+\beta_{5} \mathrm{OS}_{\mathrm{i}, \mathrm{t}}+ \\
& \beta_{6} \text { SEG }_{i, t}+\beta_{7} \text { LEV }_{i, t}+\beta_{8} \text { ROA }_{i, t}+\beta_{9} \text { LOSS }_{i, t}+\beta_{10} \text { BIG }_{i, t}+\beta_{11} \text { IA }_{i, t}+\beta_{12} \text { NAF }_{i, t} \\
& +\beta_{13} \mathrm{MV}_{\mathrm{i}, \mathrm{t}}+\beta_{14} \mathrm{MTB}_{\mathrm{i}, \mathrm{t}}+\beta_{\mathrm{i}} \mathrm{IND}_{\mathrm{i}}+\beta_{\mathrm{t}} \mathrm{YEAR}_{, \mathrm{t}}+\varepsilon_{\mathrm{i}, \mathrm{t}}
\end{aligned}
$$

Table 10. Test results using market-to-book value and market value of the firm as additional control variables.

\begin{tabular}{ccccc}
\hline \multirow{2}{*}{$\begin{array}{c}\text { Independent } \\
\text { Variables }\end{array}$} & \multicolumn{4}{c}{ Dependent Variable: LN(AF) } \\
\cline { 2 - 5 } & Model 14 & \multicolumn{2}{c}{ Model 15 } \\
\cline { 2 - 5 } & Coefficient & t-Value & Coefficient & t-Value \\
\hline Constant & 5.894 & $12.108^{* * *}$ & 5.908 & $7.786^{* * *}$ \\
ESO & 0.158 & $4.898^{* * *}$ & & \\
PESO & & & 0.177 & $2.034^{* *}$ \\
LN(TA) & 0.433 & $23.200^{* * *}$ & 0.398 & $6.618^{* * *}$ \\
REC & 0.214 & 1.083 & 0.179 & 0.697 \\
INV & 0.442 & $1.713^{*}$ & 0.239 & 0.662 \\
OS & -0.082 & -1.110 & -0.022 & -0.194 \\
SEG & 0.014 & 0.878 & 0.003 & 0.112 \\
LEV & -0.008 & -0.070 & 0.001 & 0.002 \\
ROA & 0.006 & 0.028 & -0.004 & -0.016 \\
LOSS & 0.043 & 1.219 & 0.023 & 0.555 \\
BIG & 0.228 & $5.171 * * *$ & 0.201 & $3.462^{* * *}$ \\
IA & 0.017 & 0.344 & -0.050 & -0.821 \\
NAF & 0.044 & 1.202 & 0.066 & 1.339 \\
MV & 0.006 & 0.906 & 0.045 & 0.848 \\
MTB & 0.002 & 0.401 & -0.004 & -0.155 \\
\hline F-Value & $83.470 * * *$ & $81.360 * * *$ \\
Adj. R ${ }^{2}$ & \multicolumn{2}{c}{0.884} & 0.931 \\
\hline
\end{tabular}

Notes: Table 10 presents test results using the market-to-book value and market value of the firm as additional control variables. ${ }^{* * *}, * *$, and $*$ indicate significance at $1 \%, 5 \%$, and $10 \%$, respectively. Estimated coefficients for industry and year dummy variables are not reported for brevity.

The empirical results of Model 14 in Table 10 show that the presence of ESO is positively related to audit fees. At the same time, Model 15 in Table 10 shows that the portion of ESO to total executive compensation has a significantly positive impact on audit fees. These results in Table 10 demonstrate that the existence of ESO (the increase in the portion of ESO to total executive compensation) leads to higher audit fees, demanded by the auditor to compensate for increase in audit risk. In short, our sensitivity test results are the same as those without considering the market-to-book value and market value of the firm as additional control variables.

\subsubsection{Test Results Using Audit Hours as Additional Dependent Variables}

In this subsection, to check the robustness of test results, we used the audit hours as additional dependent variables. We measured audit hours as the natural log of total audit hours of firms, which they are required to disclose in the annual reports filed with the Financial Supervisory Services. The empirical results of Model 16 in Table 11 show that the presence of ESO is positively related to audit hours. Model 17 in Table 11 shows that the portions of ESO to total executive compensation has a significantly positive impact on audit hours. These results in Table 11 demonstrate that the existence of 
ESO (the increase in the portion of ESO to total executive compensation) leads to higher audit efforts, which results in higher audit hours demanded by the auditor to deal with the increase in audit risk.

$$
\begin{aligned}
& \left.\mathrm{LN}(\mathrm{AH})_{\mathrm{i}, \mathrm{t}}=\alpha+\beta_{1} \mathrm{ESO}_{\mathrm{i}, \mathrm{t}} \mathrm{PESO}_{\mathrm{i}, \mathrm{t}}\right]+\beta_{2} \mathrm{LN}(\mathrm{TA})_{\mathrm{i}, \mathrm{t}}+\beta_{3} \mathrm{REC}_{\mathrm{i}, \mathrm{t}}+\beta_{4} \mathrm{INV}_{\mathrm{i}, \mathrm{t}}+\beta_{5} \mathrm{OS}_{\mathrm{i}, \mathrm{t}}+\beta_{6} \mathrm{SEG}_{\mathrm{i}, \mathrm{t}} \\
& +\beta_{7} \mathrm{LEV}_{\mathrm{i}, \mathrm{t}}+\beta_{8} \mathrm{ROA}_{\mathrm{i}, \mathrm{t}}+\beta_{9} \mathrm{LOSS}_{i, \mathrm{t}}+\beta_{10} \mathrm{BIG}_{\mathrm{i}, \mathrm{t}}+\beta_{11} \mathrm{IA}_{\mathrm{i}, \mathrm{t}}+\beta_{12} \mathrm{NAF}_{\mathrm{i}, \mathrm{t}} \\
& +\beta_{13} \mathrm{MA}_{\mathrm{i}, \mathrm{t}}+\beta_{14} \mathrm{MTB}_{\mathrm{i}, \mathrm{t}}+\beta_{\mathrm{i}} \mathrm{IND}_{\mathrm{i}}+\beta_{\mathrm{t}} \mathrm{YEAR}_{\mathrm{t}}+\varepsilon_{\mathrm{i}, \mathrm{t}}
\end{aligned}
$$

\begin{tabular}{|c|c|c|c|c|}
\hline \multirow{3}{*}{$\begin{array}{l}\text { Independent } \\
\text { Variables }\end{array}$} & \multicolumn{4}{|c|}{ Dependent Variable: LN(AH) } \\
\hline & \multicolumn{2}{|c|}{ Model 16} & \multicolumn{2}{|c|}{ Model 17} \\
\hline & Coefficient & t-Value & Coefficient & t-Value \\
\hline Constant & -5.959 & $-7.719^{* * *}$ & -4.790 & $-4.056^{* * *}$ \\
\hline ESO & 0.141 & $2.808^{* * *}$ & & \\
\hline PESO & & & 0.224 & $1.713^{*}$ \\
\hline $\mathrm{LN}(\mathrm{TA})$ & 0.451 & $14.974^{* * *}$ & 0.456 & $6.720^{* * *}$ \\
\hline REC & 0.283 & 0.898 & 0.240 & 0.605 \\
\hline INV & 0.510 & 1.275 & 0.205 & 0.374 \\
\hline OS & -0.048 & -0.406 & -0.035 & -0.210 \\
\hline SEG & -0.002 & -0.065 & 0.030 & 0.822 \\
\hline LEV & 0.147 & 0.867 & 0.169 & 0.678 \\
\hline ROA & 0.206 & 0.620 & 0.448 & 1.116 \\
\hline LOSS & -0.015 & -0.282 & -0.091 & -1.423 \\
\hline BIG & 0.252 & $3.565^{* * *}$ & 0.241 & $2.627^{* * *}$ \\
\hline IA & -0.065 & -0.815 & -0.072 & -0.774 \\
\hline NAF & 0.049 & 0.883 & 0.079 & 1.062 \\
\hline MV & 0.007 & 0.617 & -0.056 & -0.885 \\
\hline MTB & 0.003 & 0.321 & -0.002 & -0.257 \\
\hline F-Value & \multicolumn{2}{|c|}{$75.18^{* * *}$} & \multicolumn{2}{|c|}{$72.11^{* * *}$} \\
\hline Adj. $R^{2}$ & \multicolumn{2}{|c|}{0.883} & \multicolumn{2}{|c|}{0.928} \\
\hline
\end{tabular}

Table 11. Test results using audit hours as additional dependent variables.

Notes: Table 11 presents test results using audit hours as additional dependent variables. ${ }^{* * *},{ }^{* *}$, and ${ }^{*}$ indicate significance at $1 \%, 5 \%$, and $10 \%$, respectively. Estimated coefficients for industry and year dummy variables are not reported for brevity.

\subsubsection{Test Results Using Lagged Explanatory Variables}

In this subsection, we performed tests using lagged explanatory variables on the right-hand side of the regression models to reduce the endogeneity problems [67]. Since lagged variables are used as instruments for the level equation, we used explanatory variables lagged one year as instruments in our test models $[67,68]$. To control for causality issues, we estimated the model with lagged explanatory variables. Table 12 presents the test results of considering the lagged explanatory variables as the independent and control variables.

$$
\begin{aligned}
& \left.\mathrm{LN}(\mathrm{AF})_{\mathrm{i}, \mathrm{t}+1}\left[\mathrm{LN}(\mathrm{AH})_{i, t+1}\right]=\alpha+\beta_{1} \mathrm{ESO}_{\mathrm{i}, \mathrm{t}} \text { PESO }_{\mathrm{i}, \mathrm{t}}\right]+\beta_{2} \mathrm{LN}(\mathrm{TA})_{\mathrm{i}, \mathrm{t}}+\beta_{3} \mathrm{REC}_{\mathrm{i}, \mathrm{t}}+\beta_{4} \mathrm{INV}_{\mathrm{i}, \mathrm{t}}+ \\
& \beta_{5} \mathrm{OS}_{\mathrm{i}, \mathrm{t}}+\beta_{6} \mathrm{SEG}_{\mathrm{i}, \mathrm{t}}+\beta_{7} \mathrm{LEV}_{\mathrm{i}, \mathrm{t}}+\beta_{8} \mathrm{ROA}_{i, \mathrm{t}}+\beta_{9} \mathrm{LOSS}_{\mathrm{i}, \mathrm{t}}+\beta_{10} \mathrm{BIG}_{\mathrm{i}, \mathrm{t}}+\beta_{11} \mathrm{IA}_{\mathrm{i}, \mathrm{t}} \\
& +\beta_{12} \mathrm{NAF}_{\mathrm{i}, \mathrm{t}}+\beta_{13} \mathrm{MA}_{\mathrm{i}, \mathrm{t}}+\beta_{14} \mathrm{MTB}_{\mathrm{i}, \mathrm{t}}+\beta_{\mathrm{i}} \mathrm{IND}_{\mathrm{i}}+\beta_{\mathrm{t}} \mathrm{YEAR}_{, \mathrm{t}}+\varepsilon_{\mathrm{i}, \mathrm{t}}
\end{aligned}
$$

The empirical results of Model 18 and Model 19 in Table 12 show that the lagged PESOs are positively related to the audit fees, as well as audit hours. These results support the evidence that the increase in the portion of ESO to total executive compensation leads to higher audit risk and, thus, higher audit efforts reflected in audit fees and audit hours. Therefore, we found that test results using lagged explanatory variables on the right-hand side of the regression models to mitigate endogeneity issue are the same as those presented in the previous subsections. 
Table 12. Test results using lagged explanatory variables.

\begin{tabular}{ccccc}
\hline \multirow{2}{*}{$\begin{array}{c}\text { Independent } \\
\text { Variables }\end{array}$} & \multicolumn{2}{c}{ Dependent Variable: LN(AF) } & \multicolumn{2}{c}{ Dependent Variable: LN(AH) } \\
\cline { 2 - 5 } & \multicolumn{2}{c}{ Model 18 } & \multicolumn{2}{c}{ Model 19 } \\
\cline { 2 - 5 } & Coefficient & t-Value & Coefficient & t-Value \\
\hline Constant & 5.220 & $6.281^{* * *}$ & -1.554 & $-1.878^{*}$ \\
PESO & 0.231 & $2.319^{* *}$ & 0.247 & $2.493^{* * *}$ \\
LN(TA) & 0.411 & $5.570^{* * *}$ & 0.395 & $5.374^{* * *}$ \\
REC & 0.335 & 1.149 & 0.337 & 1.159 \\
INV & 0.783 & $1.940^{*}$ & 0.893 & $2.221^{* *}$ \\
OS & -0.070 & -0.575 & -0.027 & -0.226 \\
SEG & -0.018 & -0.666 & -0.028 & -1.058 \\
LEV & 0.160 & 0.762 & 0.278 & 1.325 \\
ROA & -0.017 & -0.056 & 0.014 & 0.049 \\
LOSS & 0.057 & 1.290 & 0.060 & 1.373 \\
BIG & 0.134 & $2.078^{* *}$ & 0.138 & $2.158^{* *}$ \\
IA & -0.095 & -1.457 & -0.100 & -1.536 \\
NAF & 0.059 & 1.166 & 0.072 & 1.437 \\
MV & 0.059 & 0.954 & 0.069 & 1.109 \\
MTB & -0.029 & -0.781 & -0.031 & -0.837 \\
\hline F-Value & \multicolumn{7}{c}{$77.33^{* * *}$} & & $77.91^{* * *}$ \\
Adj. R ${ }^{2}$ & 0.942 & & 0.942 & \\
\hline
\end{tabular}

Notes: Table 12 presents test results using lagged explanatory variables. ${ }^{* * *}, * *$, and ${ }^{*}$ indicate significance at $1 \%, 5 \%$, and $10 \%$, respectively. Estimated coefficients for industry and year dummy variables are not reported for brevity.

\subsubsection{Test Results Applying System GMM Estimation}

In this subsection, to control for causality issues, we fit the relationship between PESO and audit fees in a dynamic panel system and apply GMM technique as robustness checks. Table 13 reports the results, applying system GMM estimation by Arellano and Bover (1995) [69] and Blundell and Bond (1998) [70] to test the model. The empirical results of Model 20 in Table 13 show that PESOs are positively related to audit fees. Therefore, we found that test results using the GMM technique to mitigate the endogeneity issue are the same as those presented in the previous subsection.

(1) Dynamic panel model:

$$
\begin{aligned}
& \mathrm{LN}(\mathrm{AF})_{i, \mathrm{t}}=\alpha+\beta_{1} \mathrm{LN}(\mathrm{AF})_{i, \mathrm{t}-1}+\beta_{2} \mathrm{PESO}_{\mathrm{i}, \mathrm{t}}+\beta_{3} \mathrm{LN}(\mathrm{TA})_{\mathrm{i}, \mathrm{t}}+\beta_{4} \mathrm{REC}_{\mathrm{i}, \mathrm{t}}+\beta_{5} \mathrm{INV}_{\mathrm{i}, \mathrm{t}}+ \\
& \beta_{6} \mathrm{OS}_{\mathrm{i}, \mathrm{t}}+\beta_{7} \mathrm{SEG}_{\mathrm{i}, \mathrm{t}}+\beta_{8} \mathrm{LE}_{\mathrm{i}, \mathrm{t}}+\beta_{9} \mathrm{ROA}_{i, \mathrm{t}}+\beta_{10} \mathrm{LOSS}_{\mathrm{i}, \mathrm{t}}+ \\
& \beta_{11} \mathrm{BIG}_{\mathrm{i}, \mathrm{t}}+\beta_{12} \mathrm{IA}_{\mathrm{i}, \mathrm{t}}+\beta_{13} \mathrm{NAF}_{\mathrm{i}, \mathrm{t}}+\beta_{\mathrm{i}} \mathrm{IND}_{\mathrm{i}}+\beta_{\mathrm{t}} \mathrm{YEAR}_{, \mathrm{t}}+\varepsilon_{\mathrm{i}, \mathrm{t}}
\end{aligned}
$$

(2) First differencing model with instrument variables for a more robust estimator:

$$
\begin{aligned}
& \Delta \mathrm{LN}(\mathrm{AF})_{\mathrm{i}, \mathrm{t}}=\alpha+\beta_{1} \Delta \mathrm{LN}(\mathrm{AF})_{\mathrm{i}, \mathrm{t}-1}+\beta_{2} \Delta \mathrm{PESO}_{\mathrm{i}, \mathrm{t}}+\beta_{3} \Delta \mathrm{LN}(\mathrm{TA})_{\mathrm{i}, \mathrm{t}}+\beta_{4} \Delta \mathrm{REC}_{\mathrm{i}, \mathrm{t}}+\beta_{5} \Delta \mathrm{INV}_{\mathrm{i}, \mathrm{t}}+ \\
& \beta_{6} \Delta \mathrm{OS}_{\mathrm{i}, \mathrm{t}}+\beta_{7} \Delta \mathrm{SEG}_{\mathrm{i}, \mathrm{t}}+\beta_{8} \Delta \mathrm{LEV}_{\mathrm{i}, \mathrm{t}}+\beta_{9} \Delta \mathrm{ROA}_{\mathrm{i}, \mathrm{t}}+\beta_{10} \Delta \mathrm{LOSS}_{\mathrm{i}, \mathrm{t}}+\beta_{11} \Delta \mathrm{BIG}_{\mathrm{i}, \mathrm{t}}+\beta_{12} \Delta \mathrm{IA}_{\mathrm{i}, \mathrm{t}} \\
& +\beta_{13} \Delta \mathrm{NAF}_{\mathrm{i}, \mathrm{t}}+\beta_{\mathrm{i}} \mathrm{IND}_{\mathrm{i}}+\beta_{\mathrm{t}} \mathrm{YEAR}_{\mathrm{t}}+\Delta \varepsilon_{\mathrm{i}, \mathrm{t}}(\text { instrument variables for differenced equation: } \\
& \Delta \mathrm{LN}(\mathrm{AF})_{\mathrm{i}, \mathrm{t}-1}, \Delta \mathrm{LN}(\mathrm{AF})_{\mathrm{i}, \mathrm{t}-2} \ldots \text { and instrument variables for level equation: LN(AF) }{ }_{\mathrm{i}, \mathrm{t}-2,} \\
& \left.\mathrm{LN}(\mathrm{AF})_{\mathrm{i}, \mathrm{t}-3 .}\right)
\end{aligned}
$$


Table 13. Test results applying system GMM estimation.

\begin{tabular}{ccc}
\hline \multirow{2}{*}{ Independent Variables } & \multicolumn{2}{c}{ Dependent Variable: LN(AF) } \\
\cline { 2 - 3 } & \multicolumn{2}{c}{ Model 20 } \\
\cline { 2 - 3 } & Coefficient & z-Value \\
\hline Constant & 4.634 & $1.810^{*}$ \\
Lagged LN(AF) & 0.923 & $9.701^{* * *}$ \\
PESO & 0.131 & $1.746^{*}$ \\
LN(TA) & -0.129 & -1.331 \\
REC & -0.396 & -1.565 \\
INV & -0.337 & -0.541 \\
OS & 0.186 & 1.111 \\
SEG & 0.082 & 1.014 \\
LEV & 0.124 & 0.437 \\
ROA & 0.605 & $2.347^{* *}$ \\
LOSS & 0.008 & 0.202 \\
BIG & 0.022 & 0.179 \\
IA & -0.097 & $-2.281^{* *}$ \\
NAF & 0.038 & 0.090 \\
\hline Wald CHI & \multicolumn{2}{c}{$202.90 * * *$} \\
\hline
\end{tabular}

Notes: Table 13 presents test results applying system GMM estimation. 1 . The overidentifying restricts are valid by Sargan test: Null hypothesis not rejected by $\mathrm{CHI}^{2}(12)=9.2436$, $\mathrm{Prob}>\mathrm{CHI}^{2}=0.6820$ and 25 instruments and 47 panels. 2. Arellano-bond test for zero autocorrelation in first-differenced errors: $\operatorname{AR}(1)$ by $z=-2.466, \operatorname{AR}(2)$ by $z=$ 1.535. 3. ${ }^{* * * * *}$, and ${ }^{*}$ indicate significance at $1 \%, 5 \%$ and $10 \%$, respectively. 4 . Estimated coefficients for industry and year dummy variables are not reported for brevity.

\section{Discussion and Conclusions}

This study analyzed how the presence of ESO and the portion of ESO compensation to total executive compensation affect audit fees. This study also unearthed whether agency problems and monitoring mechanisms influence the effect of ESO on audit fees. We used 231 firm-year observations with ESO as analysis samples and 231 matching observations without ESO as control samples, selected from nonfinancial Korean listed companies for the period 2000-2005. The primary results of this study are as follows.

First, we found that audit fees are significantly higher for firms with ESO than those for firms without ESO. In addition, using firms with ESO, we also found that the portion of ESO to total executive compensation has a significantly positive effect on audit fees. These results indicate that ESO leads to an increase in audit risk, which results in higher audit fees.

Second, we found that the effect of ESO on audit fees is even higher for firms with high agency problems, both between managers and stockholders and between minority and majority stockholders. These results support the suggestion that higher agency problems can raise audit risk, resulting in higher audit fees.

Third, we found that the effect of ESO on audit fees is higher for firms with effective internal monitoring mechanisms and major accounting firms. These results support the view that an effective monitoring system is positively associated with the demand for high-quality external audit services.

As there are relatively few studies on whether executive equity incentives such as stock option affect auditors' risk assessments and pricing decisions, this study may provide additional evidence on the association. Likewise, since there are little empirical evidence on the relationship between executive stock option and audit fees in the US, this study using unexplored data from a fast growing Korean stock market may provide new evidence on the relationship in emerging markets. Moreover, this study suggests the moderating effects of circumstances such as agency problems and monitoring systems on the association, which are different from those of developed countries. Thus, this study will contribute to future research on the impact of executive stock option on managerial decision making 
in the emerging markets. Furthermore, our empirical result supports the complementary view that effective internal monitoring mechanisms and external audit work complement each other.

This study also contributes to auditing practice. As the presence of ESO as well as the increase in the portion of ESO to total executive compensation lead to higher audit risk and thus higher audit fees demanded by the auditor to compensate for the increase in audit risk, regulatory agencies can validate the provisions of ISA No. 240 and No. 315 that consider ESO a significant risk factor. At the same time, since there are relatively few studies on whether executive equity incentives, such as stock option, affect auditors' risk assessments and pricing decisions, these results can help external auditors in emerging markets to set up the specific guidelines for pricing audit fees. Moreover, as the presence of ESO as well as the increase in the portion of ESO to total executive compensation are likely to be examples of risk factors relating to misstatements arising from fraudulent financial reporting, regulatory agencies can use the test results as a basis for extending the disclosure on executive stock option. In sum, the results of this study will contribute to the construction of a more desirable corporate governance system in Korea, which in turn would not only enhance firm value but also strengthen the sustainability of Korean companies. Furthermore, the results of this study will provide companies in emerging markets with significant opportunities to improve corporate governance structure and auditing practice.

We suggest several directions for future research. We need to closely examine the association between the price and risk incentive of ESO and audit fees. In addition, using ESO repricing, exercise, and disposition as additional moderating variables, we can test the effect of ESO on audit fees. Furthermore, we can test the moderating effect of the state of the economy on the association between ESO and audit fees, since the state of the economy may have different effects on risk taking.

Author Contributions: S.C.L. and J.P. designed the research framework and wrote the paper. Y.L. analyzed the data. M.R. guided this work and provided extensive revisions during the study.

Funding: This work was supported by the Dongguk University Research Fund of 2018 (S-2018-G0001-00053). At the same time, this work was supported by the Ministry of Education of the Republic of Korea and the National Research Foundation of Korea [NRF-2017S1A5A2A01025232].

Conflicts of Interest: The authors declare no conflict of interest.

\section{References}

1. Jensen, M.; Murphy, K. Performance pay and top management incentives. J. Political Econ. 1990, 98, 225-264. [CrossRef]

2. Hanlon, M.; Rajgopal, S.; Shevlin, T. Are executive stock options associated with future earnings? J. Account. Econ. 2003, 36, 3-43. [CrossRef]

3. Bergstresser, D.; Philippon, T. CEO incentive and earnings management. J. Financ. Econ. 2006, 80, 511-529. [CrossRef]

4. Peng, L.; Roell, A. Executive pay and shareholder litigation. Rev. Financ. 2008, 12, 141-184. [CrossRef]

5. Larcker, D.; Richardson, S. Fees paid to audit firms, accrual choices, and corporate governance. J. Account. Res. 2004, 42, 625-658. [CrossRef]

6. Teoh, S.; Welch, I.; Wong, T. Earnings management and the post-issue performance of seasoned equity offerings. J. Financ. Econ. 1998, 50, 63-99. [CrossRef]

7. Ball, R.; Shivakumar, L. Earnings quality at initial public offerings. J. Account. Econ. 2008, 45, 324-349. [CrossRef]

8. Billing, M.; Lewis, M. Opportunism and the Related Consequences in the IPO Setting; Working paper; New York University: New York, NY, USA, 2010.

9. Baker, T.; Collins, D.; Reitenga, A. Stock option compensation and earnings management incentives. J. Account. Audit. Financ. 2003, 18, 557-582.

10. Bartov, E.; Mohanram, P. Private information, earnings manipulations and executive stock option exercises. Account. Rev. 2004, 79, 889-920. [CrossRef] 
11. Cohen, D.; Zarowin, P. Accrual-based and real earnings management activities around seasonal equity offerings. J. Account. Econ. 2010, 50, 2-19. [CrossRef]

12. Badertscher, B. Overvaluation and the choice of alternative earnings management mechanisms. Account. Rev. 2011, 86, 1491-1518. [CrossRef]

13. Shust, E. Does research and development activity increase accrual-based earnings management? J. Account. Audit. Financ. 2015, 30, 373-401. [CrossRef]

14. Zang, A. Evidence on the tradeoff between real manipulation and accrual manipulation. Account. Rev. 2011, 87, 675-703. [CrossRef]

15. Bedard, J.; Johnstone, K. Earnings manipulation risk, corporate governance risk, and auditors' planning and pricing decisions. Account. Rev. 2004, 79, 277-304. [CrossRef]

16. Kuang, Y.; Qin, B. Credit ratings and CEO risk-taking incentives. Contemp. Account. Res. 2013, 30, 1524-1559. [CrossRef]

17. Fargher, N.; Jiang, A.; Yu, Y. How do auditors perceive CEO's risk taking incentives? Account. Financ. 2014, 54, 1157-1181. [CrossRef]

18. Kim, Y.; Li, H.; Li, S. CEO equity incentives and audit fees. Contemp. Account. Res. 2015, 32, 608-638. [CrossRef]

19. Burns, N.; Kedia, S. The impact of CEO incentives on misreporting. J. Financ. Econ. 2006, 79, 35-67. [CrossRef]

20. Jensen, M.; Meckling, W. Theory of the firm: Managerial behavior, agency cost and ownership structure. J. Financ. Econ. 1976, 3, 305-360. [CrossRef]

21. Bushman, R.; Piotroski, J.; Smith, A. What determines corporate transparency? J. Account. Res. 2004, 42, 207-252. [CrossRef]

22. Bell, T.; Landsman, W.; Miller, B.; Yeh, S. The valuation implications of employee stock option accounting for profitable computer software firms. Account. Rev. 2002, 77, 971-996. [CrossRef]

23. Chung, R.; Firth, M.; Kim, J. Earnings management, surplus free cash flow, and external monitoring. J. Bus. Res. 2005, 58, 766-776. [CrossRef]

24. Claessens, S.; Djankov, S.; Fan, J.; Lang, L. Disentangling the incentive and entrenchment effects of large shareholdings. J. Financ. 2002, 57, 2741-2772. [CrossRef]

25. Haw, I.; Hu, B.; Hwang, L.; Wu, W. Ultimate ownership, income management, and legal and extra-legal institutions. J. Account. Res. 2004, 42, 423-462. [CrossRef]

26. Kim, J.; Cheong, H. Ownership structure, business group affiliation, listing status, and earnings management: Evidence from Korea. Contemp. Account. Res. 2006, 23, 427-464. [CrossRef]

27. Fan, J.; Wong, T. Do external auditors perform a corporate governance role in emerging markets? Evidence from East Asia. J. Account. Res. 2005, 43, 35-72. [CrossRef]

28. Beasley, M.; Salterio, S. The relationship between board characteristics and voluntary improvements in audit committee composition and experience. Contemp. Account. Res. 2001, 18, 539-570. [CrossRef]

29. Klein, A. Audit committee, board of director characteristics, and earnings management. J. Account. Econ. 2002, 33, 375-400. [CrossRef]

30. Abbott, L.; Parker, S.; Peters, G.; Raghunandam, K. The association between audit committee characteristics and audit fees. Audit. J. Pract. Theory 2003, 22, 17-32. [CrossRef]

31. Hay, D.; Knechel, W.; Ling, N. Evidence on the impact of internal control and corporate governance on audit fees. Int. J. Audit. 2008, 12, 9-24. [CrossRef]

32. Xie, B.; Davidson, W.; DaDalt, P. Earnings management and corporate governance: The role of the board and the audit committee. J. Corp. Financ. 2003, 9, 295-316. [CrossRef]

33. Abbott, L.; Parker, S.; Peters, G. Audit committee characteristics and restatements. Audit. J. Pract. Theory 2004, 23, 69-87. [CrossRef]

34. Bruynseels, L.; Cardinaels, E. The audit committee: Management watchdog or personal friend of the CEO? Account. Rev. 2014, 89, 113-145. [CrossRef]

35. Carcello, J.; Neal, T.; Palmrose, Z.-V.; Scholz, S. CEO involvement in selecting board members, audit committee effectiveness, and restatements. Contemp. Account. Res. 2011, 28, 396-430. [CrossRef]

36. DeAngelo, L. Auditor independence, 'low balling', and disclosure regulation. J. Account. Econ. 1981, 3, 113-127. [CrossRef]

37. DeFond, M.; Francis, J.; Wong, T. Auditor industry specialization and market segmentation: Evidence from Hong Kong. Audit. J. Pract. Theory 2000, 19, 49-66. [CrossRef] 
38. Francis, J.; Reichelt, K.; Wang, D. The pricing of national and city-specific reputations for industry expertise in the U.S. audit market. Account. Rev. 2005, 80, 113-136. [CrossRef]

39. Francis, J. The effect of audit firm size on audit prices: A study of the Australian market. J. Account. Econ. 1984, 6, 133-151. [CrossRef]

40. Simon, D.; Francis, J. The effects of auditor change on audit fees: Tests of price cutting and price recovery. Account. Rev. 1988, 63, 255-269.

41. Abudy, M.; Benninga, S. Non-marketability and the value of employee stock options. J. Bank. Financ. 2013, 37, 5500-5510. [CrossRef]

42. Lee, K.; Lee, S.; Choi, S. Relationship between executive stock option exercises and earnings management. Asia-Pac. J. Financ. Stud. 2011, 40, 856-888. [CrossRef]

43. Simunic, D. The pricing of audit services: Theory and evidence. J. Account. Res. 1980, 18, 161-190. [CrossRef]

44. Carcello, J.; Hermanson, D.; Neal, T.; Riley, R., Jr. Board characteristics and audit fees. Contemp. Account. Res. 2002, 19, 365-384. [CrossRef]

45. Choi, J.; Kim, J.; Zang, Y. Do abnormally high audit fees impair audit quality? Audit. J. Pract. Theory 2010, 29, 115-140. [CrossRef]

46. Baek, J.; Kang, J.; Park, K. Corporate governance and firm value: Evidence from Korean financial crisis. J. Financ. Econ. 2004, 71, 265-313. [CrossRef]

47. Zaman, M.; Hudiab, M.; Haniffa, R. Corporate governance quality, audit fees and non-audit services fees. J. Bus. Financ. Account. 2011, 38, 165-197. [CrossRef]

48. Francis, J. A framework for understanding and researching audit quality. Audit. J. Pract. Theory 2011, 30, 125-152. [CrossRef]

49. Lawrence, A.; Minutti-Meza, M.; Zhang, P. Can big 4 versus non-big 4 differences in audit-quality proxies be attributed to client characteristics? Account. Rev. 2011, 86, 259-286. [CrossRef]

50. O'Keefe, T.; King, R.; Gaver, K. Audit fees, industry specialization, and compliance with GAAS reporting standards. Audit. J. Pract. Theory 1994, 13, 41-55.

51. Clatworthy, M.; Peel, M. The effect of corporate status on external audit fees: Evidence form the UK. J. Bus. Financ. Account. 2007, 34, 169-201. [CrossRef]

52. Hay, D.; Knechel, W.; Wong, N. Audit fees: A meta-analysis of the effect of supply and demand attributes. Contemp. Account. Res. 2006, 23, 141-191. [CrossRef]

53. Francis, J.; Simon, T. A test of audit pricing in the small-client segment of the U.S. audit market. Account. Rev. 1987, 62, 145-157.

54. Ball, R.; Jayaraman, S.; Shivakumar, L. Audited financial reporting and voluntary disclosure as complements: A test of the conformation hypothesis. J. Account. Econ. 2012, 53, 136-166. [CrossRef]

55. Chaney, P.; Jeter, D.; Shivakumar, L. Self-selection of auditors and audit pricing in private firms. Account. Rev. 2004, 79, 51-73. [CrossRef]

56. Francis, J.; Stokes, D. Audit prices, product differentiation, and scale economies: Further evidence from the Australian market. J. Account. Res. 1986, 24, 383-393. [CrossRef]

57. Craswell, A.; Francis, J.; Traylor, S. Auditor brand name reputations and industry specializations. J. Account. Econ. 1995, 20, 297-322. [CrossRef]

58. Abdel-khalik, A. The jointness of audit fees and demand for MAS: A self-selection analysis. Contemp. Account. Res. 1990, 6, 295-322. [CrossRef]

59. Davis, L.; Ricchiute, D.; Trompeter, G. Audit effort, audit fees and the provision of non-audit services to audit clients. Account. Rev. 1993, 68, 135-150.

60. Palmrose, Z. The audit fees and auditor size: Further evidence. J. Account. Res. 1986, 24, 97-110. [CrossRef]

61. Simunic, D. Auditing, consulting and auditor independence. J. Account. Econ. 1984, 22, 3-35. [CrossRef]

62. Whisenant, S.; Sankaraguruswamy, S.; Raghunandan, S. Evidence on the joint determination of audit and non-audit fees. J. Account. Res. 2003, 41, 721-744. [CrossRef]

63. Laeven, L.; Levine, R. Complex ownership structures and corporate valuations. Rev. Financ. Stud. 2008, 21, 579-604. [CrossRef]

64. Core, J.; Guay, W. The use of equity grants to manage optimal equity incentive levels. J. Account. Econ. 1999, 28, 151-184. [CrossRef]

65. Core, J.; Guay, W. Stock option plans for non-executive employees. J. Financ. Econ. 2001, 61, $253-287$. [CrossRef] 
66. Mehran, H.; Tracy, J. The effect of employee stock options on the evolution of compensation in the 1990 s. In Economic Policy Review; FRB: New York, NY, USA, 2001; pp. 17-34.

67. Abdalla, W.; Goergen, M.; O'Sullivan, N. Endogeneity: How failure to correct for it can cause wrong inferences and some remedies. Br. J. Manag. 2015, 26, 791-804. [CrossRef]

68. Jayaraman, S.; Milbourn, T. CEO incentives and financial misreporting: The role of auditor expertise. Account. Rev. 2014, 90, 321-350. [CrossRef]

69. Arellano, M.; Bover, O. Another look at the instrumental variable estimation of error-components models. J. Econ. 1995, 68, 29-51. [CrossRef]

70. Blundell, R.; Bond, S. Initial conditions and moment restrictions in dynamic panel-data models. J. Econ. 1998, 87, 115-143. [CrossRef]

(C) 2018 by the authors. Licensee MDPI, Basel, Switzerland. This article is an open access article distributed under the terms and conditions of the Creative Commons Attribution (CC BY) license (http:/ / creativecommons.org/licenses/by/4.0/). 